\title{
Targets of curcumin
}

\author{
Hongyu Zhou ${ }^{1}$, Christopher S. Beevers ${ }^{1}$, and Shile Huang ${ }^{1,2,{ }^{*}}$ \\ ${ }^{1}$ Department of Biochemistry and Molecular Biology, Louisiana State University Health Sciences \\ Center, 1501 Kings Highway, Shreveport, LA 71130-3932, USA \\ ${ }^{2}$ Feist-Weiller Cancer Center, Louisiana State University Health Sciences Center, 1501 Kings \\ Highway, Shreveport, LA 71130-3932, USA
}

\section{Abstract}

Curcumin (diferuloylmethane), an orange-yellow component of turmeric or curry powder, is a polyphenol natural product isolated from the rhizome of the plant Curcuma longa. For centuries, curcumin has been used in some medicinal preparation or used as a food-coloring agent. In recent years, extensive in vitro and in vivo studies suggested curcumin has anticancer, antiviral, antiarthritic, anti-amyloid, antioxidant, and anti-inflammatory properties. The underlying mechanisms of these effects are diverse and appear to involve the regulation of various molecular targets, including transcription factors (such as nuclear factor- $\mathrm{KB}$ ), growth factors (such as vascular endothelial cell growth factor), inflammatory cytokines (such as tumor necrosis factor, interleukin 1 and interleukin 6), protein kinases (such as mammalian target of rapamycin, mitogen-activated protein kinases, and Akt) and other enzymes (such as cyclooxygenase 2 and 5 lipoxygenase). Thus, due to its efficacy and regulation of multiple targets, as well as its safety for human use, curcumin has received considerable interest as a potential therapeutic agent for the prevention and/or treatment of various malignant diseases, arthritis, allergies, Alzheimer's disease, and other inflammatory illnesses. This review summarizes various in vitro and in vivo pharmacological aspects of curcumin as well as the underlying action mechanisms. The recently identified molecular targets and signaling pathways modulated by curcumin are also discussed here.

\section{Keywords}

Curcumin; molecular targets; transcription factors; growth factors; inflammatory cytokines; protein kinases; enzymes

\section{Introduction}

Turmeric (the common name for Curcuma Longa, known as haldi in Hindi) is an Indian spice that belongs to the ginger family [1]. Besides the use as a spice, food preservative and coloring agent, turmeric has been traditionally used in Ayurvedic medicine for the treatment of various ailments such as arthritis, ulcers, jaundice, wounds, fever, trauma as well as skin diseases like psoriasis [2]. Curcumin, a hydrophobic polyphenol, is a principal active constituent of turmeric. In addition to curcumin, turmeric also contains other constituents termed curcuminoids. Curcumin, demethoxycurcumin, bisdemethoxycurcumin, and the recently identified cyclocurcumin are the major curcuminoids isolated from turmeric [3].

*Correspondence to: Department of Biochemistry and Molecular Biology Louisiana State University Health Sciences Center 1501 Kings Highway, Shreveport, LA 71130-3932, USA Phone: (318) 675-7759; Fax: (318) 675-5180 shuan1@1suhsc.edu .

Conflict of interest statement None declared. 
Several studies have shown that curcumin is more active than demethoxycurcumin or bisdemethoxycurcumin $[4,5]$. Commercial available preparations of "curcumin" contain approximately $77 \%$ curcumin, $17 \%$ demethoxycurcumin and $3 \%$ bisdemethoxycurcumin.

Curcumin was first isolated in impure form in 1815 by Vogel and Pelletier, and its chemical structure and synthesis was confirmed by Lampe et al. in 1910 and 1913, respectively [6,7]. Chemically, curcumin is a bis- $\alpha, \beta$-unsaturated $\beta$-diketone, named $(E, E)$-1,7-bis (4hydroxy-3-methoxyphenyl)-1,6-heptadiene-3,5 dione [6] (Fig. 1). The first study on the use of curcumin in human diseases was published in 1937 [8]. Its antibacterial effect and the ability to decrease blood sugar levels in human subjects was documented in 1949 and 1972, respectively [1]. Over the last 60 years, more than 3000 studies have demonstrated curcumin has antioxidant, antibacterial, antifungal, antiviral, anti-inflammatory, antiproliferative, proapoptotic and anti-atherosclerotic effects, exerting medicinal benefits against neurodegenerative diseases, arthritis, allergy, inflammatory bowel disease, nephrotoxicity, AIDS, psoriasis, diabetes, multiple sclerosis, cardiovascular disease, and lung fibrosis [9-12] (Fig. 2). These effects of curcumin have attracted considerable interests of researchers to uncover its multiple cellular targets and the molecular mechanisms underlying these biological properties. Evidence indicates that the pleiotropic effects of curcumin are dependent on its capacity of interacting and regulation of multiple molecular targets (Table 1). These targets include transcription factors, growth factors, kinases, inflammatory cytokines, adhesion molecules, apoptosis-related proteins and others. Herein, we present a brief review summarizing the recently identified molecular targets and signaling pathways modulated by curcumin. Various in vitro and in vivo pharmacological aspects of curcumin as well as the underlying action mechanisms are also discussed here. Because of space limitation, we apologize for not being able to cite all related published studies. The readers who are particularly interested in learning more on curcumin as a therapeutic agent are referred to the excellent review articles $[13,14]$.

\section{Molecular targets of curcumin}

Modern scientific researches demonstrated curcumin is a highly pleiotropic molecule that interacts with its numerous molecular targets. Curcumin may directly bind and modulate their activity, or indirectly regulate their functions. More than 30 different proteins have been found to interact with curcumin directly, including DNA polymerase [15], focal adhesion kinase (FAK) [16], thioredoxin reductase [17], protein kinase (PK) C [18], lipoxygenase (LOX) [19], and tubulin [20]. It has also been shown that curcumin can bind to certain divalent metal ions such as $\mathrm{Fe}, \mathrm{Cu}, \mathrm{Mn}$ and $\mathrm{Zn}[21,22]$.

\subsection{Transcription factors}

The transcription factors affected by curcumin might be activated or inhibited depending on the particular target. As shown in Table 1, curcumin potently inhibits the activation of some transcription factors including nuclear factor- $\mathrm{\kappa B}$ (NF- $\mathrm{\kappa B}$ ) [23], activated protein-1 (AP-1) [24], signal transducer and activator of transcription (STAT) proteins [25,26], hypoxiainducible factor-1 (HIF-1) [27], Notch-1 [28], early growth response-1 (Egr-1) [29] and $\beta$ catenin [30], but activates other transcription factors such as aryl hydrocarbon receptor (AhR) [31], activating transcription factor (ATF) 3 [32], C/EBP homologous protein (CHOP) [33], electrophile response element (EpRE) [34], peroxisome preoliferatoractivated receptor-gamma (PPAR- $\gamma$ ) [35], and NF-E2-related factor (Nrf2) [36].

It has been shown that the nuclear factors, AP-1, NF-кB, STAT-3, $\beta$-catenin, Egr-1, HIF-1 and Notch-1, are involved in cell proliferation, cell survival, invasion, angiogenesis, tumorigenesis and inflammation. In most cancers, these transcription factors are upregulated. NF- $\kappa B$, representing a family of eukaryotic transcription factors, plays an 
essential role in regulating the expression of a wide range of genes critical for innate and adaptive immunity, inflammation and cell survival $[37,38]$. Dysregulated NF- $\mathrm{KB}$ activity occurs in a number of diseases, particularly cancer, chronic and acute inflammatory diseases. In non-stimulated cells, NF- $\mathrm{kB}$ is constitutively localized in the cytosol as a heterodimer by physical association with an inhibitory protein called inhibitor $\kappa \mathrm{B}$ (I $\kappa \mathrm{B}$ ) $[37,39,40]$. Various pathogenic stimuli, including bacterial products, carcinogens, tumor promotors, cytokines, radiation, ischemia/reperfusion, and oxidants can activate NF- $\mathrm{KB}$ via several signal transduction pathways. Upon activation, NF- $\mathrm{KB}$ is translocated to the nucleus, where it induces the expression of more than 200 target genes that have been shown to induce cell proliferation, invasion, metastasis, chemoresistance, and/or inflammation [41]. The expression of constitutively active NF- $\mathrm{kB}$ has been reported in most of human cancer cell line and tumors, including breast cancer [42], gynecologic cancer [43], gastrointestinal cancer [44], head and neck squamous cell carcinoma [45], hematological cancer [46], and melanoma [47]. Curcumin prevents NF- $\mathrm{kB}$ activation induced by various agents through inhibiting p65 translocation to the nucleus and suppressing I $\kappa \mathrm{B} \alpha$ degradation in numerous cell types [48]. By inhibiting NF- $\kappa B$ activation, curcumin suppresses the expression of various cell survival and proliferative genes, including Bcl-2, Bcl-xL, cyclin D1, interleukin (IL)-6, cyclooxygenase 2 (COX-2) and matrix metallopeptidase (MMP)-9, and subsequently arrests cell cycle, inhibits proliferation, and induces apoptosis [49].

It has been identified that significant cross-talk and stimulation occurs between the Notch and NF- $\mathrm{kB}$ pathways, both of which are important regulators of cell proliferation and survival, and are key factors in carcinogenesis [28]. The Notch family of genes (Notch-1, -2 , $-3,-4$ ) encode a group of single-pass transmembrane cell-surface receptors that can be activated by interacting with a family of its ligands [50,51]. Upon activation, Notch is cleaved, generating the nuclear transcriptional co-activator intracellular Notch (ICN). Released ICN translocates into the nucleus where it functions as a transcriptional coactivator by binding the CBF1/RBP-J $/ / S u p p r e s s o r$ of Hairless/LAG-1 (CSL) transcription factor. This binding event stimulates further co-activator recruitment and transcriptional activation of Notch target genes that modulate key processes such as cell growth and development, particularly hematopoietic events in cells of the immune system [50]. Curcumin downregulates Notch-1 signaling, which results in the inactivation of NF- $\mathrm{BB}$ activity, and contributes to cell growth inhibition and apoptosis in pancreatic cancer cells [28]. Furthermore, silencing expression of Notch-1 by RNA interference inhibits NF- $\kappa B$ DNA binding and sensitizes cells to curcumin inhibition of cell growth, survival and NF- $\mathrm{BB}$ activity. On the other hand, overexpression of Notch-1 attenuates curcumin-mediated cell growth suppression, cell death, and NF- $\mathrm{KB}$ inhibition [28].

AP-1, which was first known as a 12-O-tetradecanoylphorbyl-13-acetate (TPA) inducible transcription factor, is another transcription factor that regulates genes responsible for cell proliferation, survival, differentiation, apoptosis, cell migration, and transformation [52]. AP-1 is a dimeric complex composed of many different proteins belonging to the c-Fos, cJun, ATF and Jun dimerization protein families [53]. These AP-1 factors can bind to the TPA-response element sequence and enhance target gene expression [54]. The specific subunit composition of the AP-1 complex determines the diverse cellular responses to AP-1 activity [55]. For example, in mouse fibroblasts c-Jun promotes S-phase entry and proliferation, whereas JunD negatively regulates cell growth [56]. It has been shown that curcumin inhibits the activation of AP-1 induced by tumor promoters via direct interaction with AP-1 binding to its DNA binding motif [57]. Curcumin increases gene expression of glutamate-cysteine ligase (GCL) and other phase II enzymes, which is due to the increased JunD and c-Jun content in AP-1 complexes and decreased MafG/MafK in EpRE complexes [58]. 
As abovementioned, curcumin can activate some transcription factors such as AhR, ATF3, CHOP, EpRE, and Nrf2. Induction of ATF3 contributes to the proapoptotic effects of this compound [32]. Nrf2 activation by curcumin has been linked to the induction of hemeoxygenase-1 (HO-1), and the increase in the expression and the promoter activity of the aldose reductase $[59,60]$. In human oral keratinocytes, curcumin initiated nuclear translocation of AhR and formation of the transcriptionally active AhR-aryl hydrocarbon receptor nuclear translocator complex, leading to the upregulation of several AhR-regulated genes [31]. The potential carcinogen bioactivator CYP1A1, one of the AhR-responsive genes, is associated with carcinogen metabolism. Curcumin significantly increased expression and function of CYP1A1, thereby inhibiting CYP1A1-mediated bioactivation of the tobacco-associated carcinogen BP-7, 8-diol in both human oral squamous cell carcinoma keratinocytes and oral mucosal tissues [31].

\subsection{Growth factors and protein kinases}

Growth factors and their receptors play a critical role in the normal process of growth and differentiation. Unregulated expression of these molecules can lead to abnormal growth and development, resulting in malignant transformation [61]. In addition, increased expression of growth factors, such as transforming growth factor- $\alpha$ (TGF- $\alpha$ ), can lead to non-neoplastic disorders like psoriasis $[62,63]$. Curcumin has been shown to modulate the expression and activity of these growth factors, thereby exhibiting antiproliferative, anti-invasive and antiangiogenic effects (Table 1).

The epidermal growth factor receptor (EGFR; ErbB-1; HER1 in humans) is an integral plasma membrane protein kinase that is composed of a cysteine-rich extracellular ligandbinding domain, a hydrophobic transmembrane domain, and intracellular C-terminal tails containing tyrosine kinase function and several tyrosine autophosphorylation sites [64,65]. It is a member of the ErbB family of receptors, which is a subfamily of four closely related receptor tyrosine kinases: EGFR (ErbB-1), HER2/c-neu (ErbB-2), Her3 (ErbB-3) and Her4 (ErbB-4) [65]. The activation of EGFR occurs primarily through ligand-dependent mechanisms, but can also occur through ligand-independent events as well as through receptor overexpression [65]. EGFR and its family members are stimulated by several distinct ligands, including epidermal growth factor (EGF), TGF- $\alpha$, amphiregulin, betacellulin, epigen, epiregulin, and heparin binding EGF-like growth factor $[65,66]$. Ligand binding to the extracellular domain of the receptor, induces the formation of receptor homoor heterodimers [67]. The formation of this receptor-dimer complex stimulates the auto- and/ or cross-phosphorylation of key tyrosine residues in the C-terminal tails of the receptor, which can function to initiate phosphorylation/signaling cascades via interaction with SH2and phosphotyrosine-binding domain containing proteins [65]. It has also been shown that the EGFR can translocate to the nucleus, where it can act as a transcription factor for cyclin D1 [65,68] and as a co-activator for STAT3 [69] and E2F1 [70]. Dysregulated EGFR signaling has been implicated as a major contributing factor to many types of cancers, such as breast [71], lung [72], colorectal [72], and head/neck cancer [72]. Specifically, the EGFR pathway plays critical roles in cancer cell proliferation, migration, survival, angiogenesis, and invasion [67,73].

The EGFR has been reported as a potential target of curcumin [74,75]. Curcumin blocks EGFR signaling by preventing EGFR tyrosine phosphorylation and suppressing EGFR gene expression that is mediated by activation of PPAR- $\gamma$ [35]. Curcumin significantly inhibited the proliferation and survival of lung adenocarcinoma PC-14 and pancreatic adenocarcinoma p34 cells, which was associated with inhibition of phosphorylation of extracellular receptor kinase (ERK) 1/2, and reduction of protein expression of COX-2 and the EGFR [76]. In addition, curcumin has been shown to inhibit the tyrosine kinase activity of the HER2/neu receptor, and deplete the protein itself [77]. Take together, suppression of 
HER2/neu and EGFR activity represents one of the mechanisms by which curcumin suppresses the growth of breast cancer cells.

Angiogenesis is a physiological process involving the growth of new blood vessels from pre-existing vessels. In cancer, angiogenesis is generally considered to be a critical step in tumor growth and metastasis [78]. Growth factors produced by tumors can stimulate vasculature formation. Curcumin may directly inhibit angiogenesis and also downregulate expression of various pro-angiogenic growth factors like vascular endothelial growth factor (VEGF), fibroblast growth factor (FGF), and EGF [79].

Estrogen and its receptors $\alpha$ and $\beta$ (ER $\alpha$ and $E R \beta)$ play important roles in the genesis and tumor progression of breast cancer [80]. As most of breast cancers express these functional receptors, modulation of ER function is a promising tool for controlling breast cancer. Curcumin has been shown to inhibit the growth of both ER-positive MCF-7 and T47D cells, as well as ER-negative MDA-MB231 cells, suggesting that curcumin may exert its chemopreventive effects independent of the expression of estrogen receptors [81].

In prostate cancer, androgens are believed to be essential at all stages of prostate cancer development [82]. It is known that the ligand-activated androgen receptor (AR) may stimulate or repress androgen-regulated genes. However, several studies suggested that AR can also be transformed in the absence of androgen [83-85]. Some cofactors or proteins, such as AP-1 and NF- $\kappa \mathrm{B}$, have been reported to be interacting with AR [86-88]. One study on AP-1 and AR interference suggested that the mutual transcriptional inhibition was because of direct protein-protein interactions between AR and AP-1, whereas another recent study showed that the cross-talk between AR and AP-1 was largely dependent on the expression of cAMP response element-binding protein (CREB)-binding protein [86,87]. The effects of curcumin on cell growth, signal transduction, and transforming activities of both androgen-dependent and-independent prostate cancer cell lines have been evaluated [89]. It appears that curcumin has potential as an anticancer agent against prostate cancer through downregulation of AR and AR-related cofactors (AP-1, NF- $\mathrm{kB}$ and CBP) [89].

Chemokine (C-X-C motif) receptor 4 (CXCR4), also called fusin, is an alpha-chemokine receptor specific for chemokine (C-X-C motif) ligand (CXCL) 12 (stromal-derived-factor-1, SDF-1). It has been shown that the CXCL12-CXCR4 axis is involved in several problematic diseases, including cancer cell metastasis [90], leukemia cell progression [91] and rheumatoid arthritis [92]. Thus, CXCR4 is thought to be one of the greatest therapeutic targets to overcome the above diseases. It has been shown that curcumin inhibited human retinal endothelial cell migration by downregulation of SDF-1 $\alpha$-induced expression of CXCR4 [93]. In follicular lymphoma cells, curcumin also exhibited inhibitory effect on CXCR4 expression, suggesting that curcumin has great potential in anti-metastatic treatment of cancer [94].

The effects of curcumin are also apparently mediated through its inhibition of other protein kinases, including autophosphorylation-activated protein kinase (AK) [18], $\mathrm{Ca}^{2+}$-dependent protein kinase (CDPK) [95], FAK [16], IL-1 receptor-associated kinase (IRAK) [96], Janus kinase (JAK) [25], mitogen-activated protein kinases (MAPKs) [97,98], the mammalian target of rapamycin (mTOR) [99,100], phosphorylase kinase $(\mathrm{PhK})[18]$, cytosolic protamine kinase (cPK) [18], PKA [18], PKB/Akt [101], PKC [98], pp60-src [18], and spleen tyrosine kinase (Syk) [102] (Table. 1). Since these protein kinases are important for cell growth, proliferation, survival, migration and other cellular events, inhibition of their functions is undoubtedly one of the action mechanisms of curcumin. Below we will further briefly discuss effects of curcumin on mTOR and MAPKs. 
mTOR is a $289 \mathrm{kDa}$ serine/threonine protein kinase that is a member of the PI3K-related kinase family of kinases [103]. mTOR functions as a master regulator of numerous key cellular processes, including cell growth [104], proliferation [105], motility [106], survival [107], autophagy [108], protein synthesis [103], and RNA Polymerase I/II/III-mediated transcription $[109,110]$. mTOR also functions as a central sensor of cellular nutrient/amino acid levels [104,111,112], cellular energy status [111], cellular redox status [113], and mitogen stimulation, particularly from insulin, IGF-1, and IGF-2 [114,115]. Dysregulation of the mTOR pathway is frequently observed in various human diseases, such as cancer and diabetes. For example, activation of the mTOR pathway was noted in squamous cancers [116], adenocarcinomas [117], bronchioloalveolar carcinomas [118], colorectal cancers [119], astrocytomas [120] and glioblastomas [121]. These findings indicate a crucial role of mTOR signaling in tumorigenesis. mTOR functions as two distinct signaling complexes, mTOR complex 1/2 (mTORC1/2). These two complexes consist of unique mTORinteracting proteins which determine their substrate specificity. A rapamycin and nutrientsensitive complex, mTORC1, consists of mTOR, raptor (regulatory associated protein of mTOR), mLST8 (also termed G-protein $\beta$-subunit-like protein, G $\beta \mathrm{L}$, a yeast homolog of LST8), and two negative regulators, PRAS40 (proline-rich Akt substrate $40 \mathrm{kDa}$ ) and DEPTOR [122-125]. The main function of mTORC1 is to regulate cell growth, proliferation and survival by sensing mitogen, energy and nutrient signals [126]. mTORC1 functions primarily in the regulation of translation initiation through signaling to its two major targets p70-S6 kinase 1 (S6K1) and eukaryotic initiation factor 4E (eIF4E) binding protein 1 (4EBP1) $[103,104]$. Like mTORC1, mTORC2 also includes mTOR and mLST8, but instead of raptor, mTORC2 contains two special subunits, rictor and $\mathrm{mSin} 1$ (mammalian stressactivated protein kinase [SAPK]-interacting protein 1) [114,127]. In addition, protor (protein observed with rictor), DEPTOR, PRR5 (proline-rich protein 5) and heat-shock protein 70 (HSP 70) are other novel components of mTORC2 [125,128-130]. mTORC2 regulates the actin cytoskeleton by mediating phosphorylation state of $\mathrm{PKC} \alpha$ [127], and modulates cell survival in response to growth factors by phosphorylating its downstream effector Akt at the hydrophobic motif site, S473 [131-133].

Several studies have shown that curcumin inhibited the mTOR pathway and the phosphorylation of S6K, resulting in the inhibition of proliferation and the induction of apoptosis, as well as the induction of autophagy $[99,100,115,134]$. Our studies demonstrated that curcumin inhibited the IGF-1-stimulated mTORC1-mediated phosphorylation of S6K1 and 4E-BP1, and mTORC2-mediated phosphorylation of Akt in a spectrum of cancer cell lines, including Rh30 (rhabdomyosarcoma), DU145 (prostate cancer), MCF-7 (breast cancer), HeLa (cervical cancer), and HT-29 (colon cancer), suggesting that curcumin inhibition of mTOR signaling was not cell- or cancer-type dependent [115]. Curcumin inhibition of Akt/mTOR/S6K signaling pathway may be related to its induction of autophagy in malignant glioma cells [100]. Most recent studies have further demonstrated that curcumin is able to dissociate raptor from mTOR, thereby inhibiting mTORC1 activity [135].

MAPKs are serine/threonine-specific protein kinases that play key roles in the transmission of extracellular stimuli (mitogens or hormones) and the regulation of various cellular activities, such as gene expression, mitosis, differentiation, cell proliferation, and cell survival/apoptosis [136]. Early studies showed that curcumin was able to inhibit c-jun Nterminal kinase (JNK) activation induced by various agonists, including phorbol 12myristate 13-acetate (PMA) plus ionomycin, anisomycin, UV-C, gamma radiation, TNF- $\alpha$, and sodium orthovanadate [137]. In MDA-MB-468 breast cancer cells, curcumin also inhibited anisomycin-induced JNK activation, as well as EGF-induced phosphorylation of ERK1/2 [138]. However, curcumin was able to induce cell apoptosis in cisplatin-resistant ovarian cancer cells, in part by activation of p38 MAPK [139]. In human astroglioma cell 
lines, curcumin potently suppressed the phosphorylation of ERK, JNK, and p38 MAP kinase, as well as MMP-9 enzymatic activity and protein expression [140]. The study also demonstrated that AP-1 was under the control of all three MAPKs, while NF- $\mathrm{BB}$ was controlled by only two MAPKs, JNK and p38, suggesting that the inhibition of curcumin on PMA-induced MMP-9 expression is mediated through the suppression of MAPKs and subsequent inhibition of NF-KB and AP-1 [140]. The inhibitory effect of curcumin on MAPKs pathway reveals a possible mechanism of AP-1 and NF- $\kappa$ B suppression, and these effects may contribute to the potent anti-inflammatory and anti-cancer effects of this chemical.

\subsection{Inflammatory cytokines}

During severe infection or after severe injury, excessive synthesis and production of proinflammatory cytokines, including TNF- $\alpha$, IL- $1 \beta$ and IL-6, play an major role in the development of local and systemic inflammation, causing severe pathophysiological derangement or organ failure [141]. Cytokine gene and protein expression are tightly controlled in the producing cells, and one of the most important steps in this regulation is gene transcription. Therefore, inhibition of pro-inflammatory cytokine production by regulation of transcriptional factors, such as NF- $\kappa \mathrm{B}$, is an potential strategy for controlling inflammatory responses [142,143]. Several studies have demonstrated that curcumin was able to modulate the production of various inflammatory cytokines, thereby exhibiting potent anti-inflammatory activity [144-146].

TNF- $\alpha$ plays an important role in the regulation of immune cells and the development of systemic inflammation [147]. Dysregulation of TNF- $\alpha$ production has been implicated in a variety of inflammatory diseases (such as rheumatoid arthritis, Crohn's disease, multiple sclerosis, and psoriasis), as well as cancer [148]. Both in vitro and in vivo studies showed that curcumin has profound inhibitory effects on the production of TNF- $\alpha$. In monocytes and alveolar macrophages, curcumin inhibited PMA- or lipopolysaccharide (LPS)- stimulated production of TNF- $\alpha$ [145]. In diabetic rats, chronic treatment with curcumin significantly reduced serum TNF- $\alpha$ level, attenuating cognitive deficit, oxidative stress and inflammation [149]. In the $\mathrm{CCl}_{4}$ rat model, curcumin protected the rat liver from $\mathrm{CCl}_{4}$-induced injury and fibrogenesis by reducing inflammatory cytokines levels in the liver and in serum, including interferon- $\gamma$ (IFN- $\gamma$ ), TNF- $\alpha$, and IL-6 [150]. In addition, curcumin also showed effects on modulation of TNF- $\alpha$-induced signaling. Singh et al. firstly reported that curcumin can down-regulate TNF- $\alpha$-induced activation of NF- $\mathrm{KB}$ and AP-1 [48]. In endothelial cells, treatment with curcumin suppressed TNF-induced NF- $\mathrm{KB}$ activation and the expression of adhesion molecules, thereby inhibiting the adhesion of monocytes to endothelial cells [151].

Interleukins are another group of inflammatory cytokines that play critical role in the regulation of inflammation response, as well as signaling pathways such as NF- $\mathrm{kB}$ and the STATs that are involved in tumor invasion and angiogenesis [152]. In TNF- $\alpha$-treated $\mathrm{HaCaT}$ cells, curcumin attenuated the expression of IL-1 $\beta$ and IL-6 through inhibition of NF- $\mathrm{KB}$ and MAPK pathways [153]. In concanavalin A (Con A), phytohemagglutinin (PHA), and PMA stimulated human lymphocytes, curcumin inhibited IL-2 synthesis and this effect may be mediated via NF- $\mathrm{kB}$ inhibition [154]. Other studies reported that curcumin also inhibited IL-5 [155], IL-8 [156,157], IL-12 [158], and IL-18 [159] expression. In addition, curcumin showed inhibitory effect on IL-12-induced STAT4 phosphorylation in human T cells [158]. In human multiple myeloma cells, curcumin inhibited IL-6-induced STAT3 phosphorylation and consequent STAT3 nuclear translocation, as well as the IFN- $\gamma$-induced STAT1 phosphorylation [160]. Other inflammatory cytokines regulated by curcumin include CXCL1 and CXCL2 [161], monocyte inflammatory protein-1 alpha (MIP-1 $\alpha$ ) [145], monocyte chemoattractant protein-1 (MCP-1) [145,162]. 


\subsection{Enzymes}

A variety of enzymes that are closely associated with inflammation and cancer were found to be modulated by curcumin. These enzymes include $\mathrm{COX}-2$, inducible nitric oxide synthase (iNOS), 5-LOX, and phospholipases A2 (PLA2).

COX-2, the inducible form of COX, can be selectively induced by mitogenic and inflammatory stimuli, which results in enhanced synthesis of prostaglandins in inflamed and neoplastic tissues $[163,164]$. Several lines of evidence showed that COX-2 is overexpressed in a wide variety of human cancers, such as colon, liver, pancreas, breast, lung, bladder, skin, stomach, head and neck cancers [163]. Either genetic downregulation of COX-2 or pharmacological inhibition of COX-2 protected against the development of tumors in animals [165-168]. Curcumin can downregulate the expression and the activity of COX-2 both in vitro and in vivo $[169,170]$. In TPA-treated mouse skin, curcumin potently inhibited the expression of COX-2 protein, as well as TPA-stimulated NF- $\kappa B$ activation [169]. In hepatocellular carcinoma cell-implanted nude mice, curcumin treatment reduced the tumorinduced overexpression of two angiogenic biomarkers, COX-2 and VEGF, indicating that curcumin could inhibit tumor angiogenesis [171]. In gastrointestinal cell lines (SK-GT-4, SCC450, IEC-18 and HCA-7), curcumin suppressed chenodeoxycholate- or PMA-induced COX-2 protein and mRNA expression [172]. Most recently, AMP-activated protein kinase (AMPK), a master regulator of cellular energy homeostasis, was found to act as a regulator of ERK1/2, p38, and COX-2 in cancer cells $[173,174]$. Regulation of AMPK-COX-2 cascade played an important role in the inhibitory effect of curcumin on adipocyte differentiation and caner cell proliferation [174]. In HT-29 colon cancer cells, curcumin exhibited a potent apoptotic effect, which was mediated by the decrease in AKT phosphorylation and COX-2 expression, as well as the increase of AMPK phosphorylation [173].

HO-1 is an enzyme that catalyzes the degradation of heme into biliverdin, iron, and carbon monoxide [175]. Induction of HO-1 is implicated in inflammatory responses in the lung [176], liver [177] and kidney [178], as well as the systemic responses to hemorrhagic shock [179]. It has been shown that curcumin inhibited glomerular fibrosis through induction of HO-1 [180]. Mechanistically, curcumin induction of HO-1 was correlated with the generation of reactive oxygen species (ROS), p38 activation and phosphatase inhibition [181].

Inosine monophosphate dehydrogenase (IMPDH) is a rate-limiting enzyme that converts inosine monophosphate to xanthosine monophosphate in the de novo biosynthesis [182]. Enhanced IMPDH enzyme expression or activity is correlated with increased cellular proliferation and malignant transformation [183,184]. Therefore, IMPDH is an attractive target of immunosuppressive, anticancer and antiviral agents. A most recent study found that curcumin potently inhibited IMPDH activity and decreased the cellular guanosine triphosphate (GTP) level in HT-29 colon carcinoma cells [185].

Other important enzymes that are downregulated by curcumin include arylamine $\mathrm{N}$ acetyltransferase [186], ATPase [187], desaturase [188], DNA polymerase [15], farnesylprotein transferase (FPTase) [189], iNOS [140], 5-LOX [190], MMP [191-193], NAD(P)H dehydrogenase quinine [194], ornithine decarboxylase (ODC) [195,196], PLA2 [190], telomerase [197,198], and xanthine oxidase (XO) [199,200]. By contrast, the enzymes that are upregulated by curcumin include GCL [201], and src homology 2 domain-containing tyrosine [202] (Table 1). Because these enzymes are involved in the regulation of cell growth, proliferation, survival, migration, invasion, and other physiological functions, inhibition of their activities clearly constitutes partial action mechanisms of curcumin. 


\subsection{Adhesion molecules}

Cell adhesion molecules (CAMs) are glycoproteins, which are located on the cell surface and are required for binding with other cells or with the extracellular matrix in the process called cell adhesion [203]. Cell surface expression of various adhesion molecules, such as intercellular cell adhesion molecule-1 (ICAM-1), vascular cell adhesion molecule-1 (VCAM-1), and endothelial leukocyte adhesion molecule-1 (ELAM-1) plays a critical role in inflammatory and neoplastic diseases [204,205]. It has been reported that inhibition of NF- $\kappa$ B completely blocked TNF- $\alpha$-induced expression of ICAM-1, VCAM-1, and Eselectin, indicating that the expression of CAMs is regulated in part by NF- $\mathrm{KB}$ [206]. In human umbilical vein endothelial cells (HUVEC), curcumin potently inhibited TNF- $\alpha$ induced expression of ICAM-1, VCAM-1, and ELAM-1 partially through NF- $\mathrm{KB}$ inhibition, and finally blocked HUVEC adhesion to monocytes [151]. Most recent studies have also shown that curcumin inhibited the expression of VCAM-1 in human intestinal microvascular endothelial cells through suppression of Akt, p38 MAPK, and NF- $\mathrm{BB}$ [207].

The integrins are a family of heterophilic CAMs that bind immunoglobulin superfamily CAMs or the extracellular matrix. During the last decade, studies on the function of integrins revealed that these molecules regulate an array of cellular processes, including cell death, proliferation, migration and differentiation [208]. It has been described that curcumintreated B16F10 melanoma cells formed eight-fold fewer lung metastases in C57BL6 mice [209]. This appears to be related to curcumin inhibition of the expression of $\alpha 5 \beta 1$ and $\alpha 5 \beta 3$ integrin receptors in $\mathrm{B} 16 \mathrm{~F} 10$ cells, as well as the cell binding to the extracellular matrix proteins, such as fibronectin, vitronectin, and collagen IV [209]. Most recent studies have further shown that curcumin directly inhibited phosphorylation of $\beta 4$ integrin (Y1494), thereby inhibiting $\alpha 6 \beta 4$-mediated breast cancer cell motility and invasion [210].

\subsection{Apoptosis-related proteins}

Apoptosis or programmed cell death, which is defined as a mechanism of cellular suicide occurring after sufficient cellular damage, is essential for the development and the maintenance of cellular homeostasis in unicellular and multicellular organisms [211]. Deregulation of apoptosis can lead to cancer, autoimmune and degenerative diseases [212]. Therefore, increasing interest has focused on the elucidation of the apoptotic pathways for disease etiology and the identification of compounds that can induce apoptosis. Studies have demonstrated that curcumin can induce apoptosis in a number of human cancer cell lines, and inhibit the tumor initiation and tumor promotion in animals [213-216]. The chemopreventive action of curcumin might be due to its ability to induce apoptosis by several pathways [139,195,217]. A microarray study has characterized apoptotic genes regulated by curcumin in tumor cells [218]. The results showed that the expression of 104 genes was altered by curcumin treatment among the 214 apoptosis-associated genes [218]. The up-regulated genes by curcumin included HIAP1, CRAF1, TRAF6, CASP1, CASP2, CASP3, CASP4, HPRT, GADD45, MCL-1, NIP1, BCL2L2, TRAP3, GSTP1, DAXX, PIG11, UBC, PIG3, PCNA, CDC10, JNK1 and RBP2. The down-regulated genes were TRAIL, TNFR, AP13, IGFBP3, SARP3, PKB, IGFBP, CASP7, CASP9, TNFSF6, TRICK2A, CAS, TRAIL-R2, RATS1, hTRIP, TNFb and TNFRSF5 [218]. In recent years, more and more targets of curcumin have been discovered in the signaling pathways implicated in apoptosis. In both PC-3 and LNCaP prostate cancer cells, curcumin elevated the expression of pro-apoptotic proteins, such as Bax, Bim, Bak, Puma, Noxa, and death receptors (TRAIL-R1/DR4 and TRAIL-R2/DR5), and inhibited the expression of antiapoptotic proteins, including B-cell lymphoma protein 2 (Bcl-2), Bcl-XL, survivin and inhibitor of apoptosis protein (IAP) [219]. In human leukemia U937 cells, curcumin downregulated the anti-apoptotic Bcl-XL, and IAP proteins, induced cytochrome c release, activated caspase- 3 and acted as a stimulator of intracellular $\mathrm{Ca}^{2+}$ uptake into mitochondria 
via uniporter pathway [220]. In human acute myelogenous leukemia HL-60 cells, curcumin induced apoptosis through mitochondrial pathway involving poly(ADP)ribose polymerase (PARP) cleavage, BID cleavage, cytochrome c release, caspase-8/3 activation [221]. In mantle cell lymphoma and multiple myeloma cell lines, curcumin activated caspase-7/9, and induced PARP cleavage [222,223]. In melanoma cells, curcumin induced apoptosis, which was dependent on activation of the death receptor Fas-initiated Fas-associated death domain (FADD)/caspase-8-dependent apoptosis pathway, but was independent of p53 and the Bcl-2 family [224]. Taken together, several apoptosis signaling pathways and apoptosis-related proteins have been implicated in curcumin-induced apoptosis. However, due to the cell specificity and the crosstalks between various apoptosis pathways, the precise action mode of curcumin still remains to be elucidated.

\subsection{Other targets}

It is well known that p53 gene is critical for cell cycle control, tumor suppression and induction of apoptosis [225]. Over half of all human cancers contain a mutation or deletion of the TP53 gene. As a transcription factor and tumor suppressor, functional p53 directly induces the expression of downstream genes such as Bax and p21 WAF1, thereby inhibiting the growth of DNA damaged cells and inducing apoptosis [226,227]. In human neuroblastoma, treatment of curcumin decreased cell viability, and induced cell cycle arrest and apoptosis. It was suggested that these effects may be mediated through functional activation of $\mathrm{p} 53$ by curcumin, followed by induction of $\mathrm{p} 21^{\mathrm{WAF} 1}$ and Bax expression [228]. In addition, several studies showed that $\mathrm{p} 53$ were overexpressed during curcumin-induced apoptosis in various cell lines such as glioma cancer, prostate cancer and breast carcinoma cells [229-231]. However, other studies showed downregulation of p53 by curcumin $[232,233]$. For example, in BKS-2 cells, an immature B cell lymphoma, curcumin decreased the expression of p53, as well as various survival gene products, including Egr-1, the protooncogene c-myc and the transmembrane antiapoptotic protein Bcl-XL [232]. In colon cancer cells, curcumin disrupted the conformation of the p53 protein required for its tumor suppression functions, including serine phosphorylation, binding to DNA, transactivation of p53-responsive genes and p53-mediated cell cycle arrest [233]. The finding of reduced p53 activity by curcumin was also observed in normal thymocytes and myeloid leukemic cells, where curcumin induced p53 degradation. Mechanistically, curcumin promoted the dissociation of $\mathrm{NAD}(\mathrm{P}) \mathrm{H}$ :quinone oxidoreductase 1 (NQO1)-p53 complexes by suppressing the activity of NQO1, a flavoenzyme that binds and stabilizes wild type p53 [194]. In terms of these contradictory reports on the effects of curcumin on p53 expression and function in different cells, it has been speculated that the potential chemopreventive effect of curcumin might relate specifically to certain types of cancer. Due to the inhibition of p53-induced apoptosis in some types of cells, curcumin treatment might confer a modest carcinogenic risk. Therefore, these cautions must always be borne in mind while using it in humans.

P300/CREB-binding protein (CBP), which is one of the most studied enzymes in the histone acetyltransferase (HAT) family, plays a role in the activation of a wide variety of genes and other cellular events. Dysfunction of HATs contributes to several diseases, including cancer, cardiac hypertrophy, and asthma [234,235]. These enzymes, therefore, represent novel, therapeutically relevant molecular targets for drug development [236]. Curcumin is a selective HAT inhibitor. It was documented that curcumin specifically repressed the P300/ CBP activity, resulting in several effects, including attenuation of inflammatory responses in human tracheal smooth muscle cells [237], inhibition of human immunodeficiency virus proliferation [238], and suppression of the proliferation of human B cell lymphoma Raji cells [239].

The other molecular targets that are affected by curcumin include cyclin D1 [240], DNA fragmentation factor 40-kd subunit [241], HSP 70 [242], multi-drug resistance protein 
(MRP) [243], urokinase-type plasminogen activator (uPA) [23], and uPA receptor [23]. Since these proteins are also important for cell growth, proliferation, survival, migration, invasion, drug resistance, and many other cellular functions, targeting them contributes to the therapeutic effect of curcumin.

\section{Human clinical trials}

Over the past years, a number of clinical trails have addressed the pharmacokinetics, safety and efficacy of curcumin in humans. Consistent with the growing in vitro and in vivo evidence of curcumin's anti-inflammatory and anti-cancer properties, disease targets include rheumatoid arthritis [244], postoperative inflammation [245], idiopathic inflammatory orbital pseudotumors [246], Alzheimer's disease, multiple myeloma [247], pancreatic cancer [247], and colon cancer [248]. The results from several preclinical and clinical trials showed that curcumin is remarkably well tolerated. Even at high doses, curcumin appears nontoxic to animals or humans $[249,250]$. A Phase I clinical trial of curcumin was conducted in patients with high risk conditions or pre-malignant lesions of the bladder, skin, cervix, stomach or oral mucosa [249]. When curcumin was administered as a single daily oral dose ranging from 500 to $8000 \mathrm{mg} /$ day for 3 months, the treatment was well tolerated [249]. In an independent dose-escalation study of curcuma extract on 15 patients with advanced colorectal cancer, curcumin extract was administered to patients at doses between 440 and $2200 \mathrm{mg} /$ day, equivalent to $36-180 \mathrm{mg}$ of curcumin, for up to 4 months. No treatmentrelated toxicity was observed at any doses either [251].

Although curcumin is well tolerated, and has a wide variety of beneficial activities, the in vivo bioavailability of curcumin is poor, which may be an important obstacle to its utility as a therapeutic agent [252]. In a clinical study, it was shown that serum levels of curcumin were undetectable or very low after $2 \mathrm{~g}$ of pure curcumin powder was administered alone to fasting volunteers [253]. A subsequent clinical phase I dose escalation study, which was conducted in 15 patients with advanced colorectal cancer refractory to standard chemotherapies, showed that consumption of $3.6 \mathrm{~g}$ of oral curcumin daily for up to 4 months results in levels of drug and conjugates in plasma near the limit of detection of the assays used, indicating the low systemic bioavailability of curcumin after oral dosing [254]. This finding is consistent with other data shown in preclinical models [255-257] and in humans $[245,249,251,253]$. Several pharmacokinetic studies of curcumin showed that curcumin seems to be metabolized through extensive conjugation and reduction in the gastrointestinal tract [252]. Curcumin undergoes avid glucuronidation and sulfation leading to the formation of curcumin glucuronide and curcumin sulfates, as well as metabolic reduction to tetrahydrocurcumin and hexahydrocurcumin, which were found in intestinal and hepatic microsomes, and cytosol, respectively [252,258]. Based on these results, it was suggested that the low systematic bioavailability of curcumin may be due to the hydrophobic nature of the molecule, poor absorption and the metabolic biotransformation in intestine and liver [10]. Several approaches have been tried to improve the bioavailability of curcumin. These approaches include: the use of adjuvants such as piperine to suppress glucuronidation in the liver [253], the use of liposomal curcumin [259], curcumin nanoparticles [260], the use of curcumin phospholipid complex [261], and the use of structural analogs of curcumin [262]. In addition, curcumin has also been conjugated with other carriers, such as cyclodextrin [263] and phosphatidylcholine [264]. Shoba et al. reported that combined treatment with curcumin and piperine $(20 \mathrm{mg} / \mathrm{kg})$ produced higher serum concentration of curcumin from $0.25-1 \mathrm{~h}$ post-drug and increased the bioavailability by $2000 \%$ [253]. A most recent study conducted to characterize the curcumin nanoparticles showed that the biodegradable curcumin nanoparticulate formulation, which was based on poly (lactide-co-glycolide) (PLGA) and a stabilizer polyethylene glycol (PEG)-5000, exhibited enhanced cellular uptake, increased bioactivity in vitro, superior bioavailability in vivo and substantially longer 
half-life than curcumin [260]. In another study, it was shown that curcumin-phospholipid complex maintained effective concentration of curcumin for a longer time in rat serum and proved better hepatoprotective activity than free curcumin at the same dose level [261]. However, there is still little information available about the in vivo efficacy and the safety of those reformulated curcumin. Therefore, more studies are required to address these questions.

\section{Conclusions}

For thousands of years, curcumin has been used in the Orient as a healing agent for a wide range of inflammatory, neoplastic and other conditions. In recent years, the great therapeutic potential against various human diseases, including cancer, cardiovascular diseases, diabetes, arthritis, neurological diseases, and HIV-disease, has been documented. According to the PubMed, over 3000 studies have been carried out with curcumin. This natural product can modulate multiple cellular signaling pathways and affect numerous molecular targets. Although curcumin is quite safe in humans, its low bioavailability may be a limitation for clinical use. Various approaches are being undertaken to enhance the bioavailability of curcumin. Obviously, more studies are needed to fully evaluate the efficacy and the safety of reformulated curcumin, the structural analogues of curcumin as well as the combination of curcumin with existing therapies. Nevertheless, the low cost, pharmacological safety, proven therapeutic efficacy and multiple targeting potential make curcumin a promising agent for prevention and treatment of various human diseases. Meanwhile, reformulations of curcumin with enhanced bioavailability may also hold great promise in the future.

\section{Acknowledgments}

The authors' work cited in this review was supported in part by NIH (CA115414 to S.H.) and American Cancer Society (RSG-08-135-01-CNE to S.H.).

\section{References}

[1]. Aggarwal BB, Sung B. Pharmacological basis for the role of curcumin in chronic diseases: an ageold spice with modern targets. Trends Pharmacol Sci 2009;30:85-94. [PubMed: 19110321]

[2]. Singh S. From exotic spice to modern drug? Cell 2007;130:765-8. [PubMed: 17803897]

[3]. Kiuchi F, Goto Y, Sugimoto N, et al. Nematocidal activity of turmeric: synergistic action of curcuminoids. Chem Pharm Bull (Tokyo) 1993;41:1640-3. [PubMed: 8221978]

[4]. Ahsan H, Parveen N, Khan NU, et al. Pro-oxidant, anti-oxidant and cleavage activities on DNA of curcumin and its derivatives demethoxycurcumin and bisdemethoxycurcumin. Chem Biol Interact 1999;121:161-75. [PubMed: 10418962]

[5]. Sandur SK, Pandey MK, Sung B, et al. Curcumin, demethoxycurcumin, bisdemethoxycurcumin, tetrahydrocurcumin and turmerones differentially regulate anti-inflammatory and antiproliferative responses through a ROS-independent mechanism. Carcinogenesis 2007;28:176573. [PubMed: 17522064]

[6]. Milobedeska J, Kostanecki V, Lampe V. Structure of curcumin. Ber Dtsch Chem Ges 1910;43:2163-70.

[7]. Lampe V, Milobedeska J. Studien über Curcumin. Ber Dtsch Chem Ges 1913;46:2235-40.

[8]. Albert O. Turmeric (curcumin) in biliary diseases. Lancet 1937;229:619-21.

[9]. Aggarwal BB, Harikumar KB. Potential therapeutic effects of curcumin, the anti-inflammatory agent, against neurodegenerative, cardiovascular, pulmonary, metabolic, autoimmune and neoplastic diseases. Int J Biochem Cell Biol 2009;41:40-59. [PubMed: 18662800]

[10]. Sharma RA, Gescher AJ, Steward WP. Curcumin: the story so far. Eur J Cancer 2005;41:195568. [PubMed: 16081279]

[11]. Aggarwal BB, Kumar A, Bharti AC. Anticancer potential of curcumin: preclinical and clinical studies. Anticancer Res 2003;23:363-98. [PubMed: 12680238] 
[12]. Shishodia S, Sethi G, Aggarwal BB. Curcumin: getting back to the roots. Ann N Y Acad Sci 2005;1056:206-17. [PubMed: 16387689]

[13]. Agrawal DK, Mishra PK. Curcumin and its analogues: Potential anticancer agents. Med Res Rev. Dec 21;2009 [Epub ahead of print].

[14]. Epstein J, Sanderson IR, Macdonald TT. Curcumin as a therapeutic agent: the evidence from in vitro, animal and human studies. Br J Nutr :1-13.

[15]. Takeuchi T, Ishidoh T, Iijima H, et al. Structural relationship of curcumin derivatives binding to the BRCT domain of human DNA polymerase lambda. Genes Cells 2006;11:223-35. [PubMed: 16483311]

[16]. Leu TH, Su SL, Chuang YC, et al. Direct inhibitory effect of curcumin on Src and focal adhesion kinase activity. Biochem Pharmacol 2003;66:2323-31. [PubMed: 14637190]

[17]. Fang J, Lu J, Holmgren A. Thioredoxin reductase is irreversibly modified by curcumin: a novel molecular mechanism for its anticancer activity. J Biol Chem 2005;280:25284-90. [PubMed: 15879598]

[18]. Reddy S, Aggarwal BB. Curcumin is a non-competitive and selective inhibitor of phosphorylase kinase. FEBS Lett 1994;341:19-22. [PubMed: 7511111]

[19]. Skrzypczak-Jankun E, Zhou K, McCabe NP, et al. Structure of curcumin in complex with lipoxygenase and its significance in cancer. Int J Mol Med 2003;12:17-24. [PubMed: 12792803]

[20]. Gupta KK, Bharne SS, Rathinasamy K, et al. Dietary antioxidant curcumin inhibits microtubule assembly through tubulin binding. Febs J 2006;273:5320-32. [PubMed: 17069615]

[21]. Baum L, Ng A. Curcumin interaction with copper and iron suggests one possible mechanism of action in Alzheimer's disease animal models. J Alzheimers Dis 2004;6:367-77. discussion 443-9. [PubMed: 15345806]

[22]. Ishihara M, Sakagami H. Re-evaluation of cytotoxicity and iron chelation activity of three betadiketones by semiempirical molecular orbital method. In Vivo 2005;19:119-23. [PubMed: 15796163]

[23]. Shin HK, Kim J, Lee EJ, et al. Inhibitory effect of curcumin on motility of human oral squamous carcinoma YD-10B cells via suppression of ERK and NF-kappaB activations. Phytother Res. 2009

[24]. Dhandapani KM, Mahesh VB, Brann DW. Curcumin suppresses growth and chemoresistance of human glioblastoma cells via AP-1 and NFkappaB transcription factors. J Neurochem 2007;102:522-38. [PubMed: 17596214]

[25]. Rajasingh J, Raikwar HP, Muthian G, et al. Curcumin induces growth-arrest and apoptosis in association with the inhibition of constitutively active JAK-STAT pathway in T cell leukemia. Biochem Biophys Res Commun 2006;340:359-68. [PubMed: 16364242]

[26]. Bhattacharyya S, Mandal D, Saha B, et al. Curcumin prevents tumor-induced T cell apoptosis through Stat-5a-mediated Bcl-2 induction. J Biol Chem 2007;282:15954-64. [PubMed: 17392282]

[27]. Bae MK, Kim SH, Jeong JW, et al. Curcumin inhibits hypoxia-induced angiogenesis via downregulation of HIF-1. Oncol Rep 2006;15:1557-62. [PubMed: 16685395]

[28]. Wang Z, Zhang Y, Banerjee S, et al. Notch-1 down-regulation by curcumin is associated with the inhibition of cell growth and the induction of apoptosis in pancreatic cancer cells. Cancer 2006;106:2503-13. [PubMed: 16628653]

[29]. Chen A, Xu J, Johnson AC. Curcumin inhibits human colon cancer cell growth by suppressing gene expression of epidermal growth factor receptor through reducing the activity of the transcription factor Egr-1. Oncogene 2006;25:278-87. [PubMed: 16170359]

[30]. Prasad CP, Rath G, Mathur S, et al. Potent growth suppressive activity of curcumin in human breast cancer cells: Modulation of Wnt/beta-catenin signaling. Chem Biol Interact 2009;181:263-71. [PubMed: 19573523]

[31]. Rinaldi AL, Morse MA, Fields HW, et al. Curcumin activates the aryl hydrocarbon receptor yet significantly inhibits (-)-benzo(a)pyrene-7R-trans-7,8-dihydrodiol bioactivation in oral squamous cell carcinoma cells and oral mucosa. Cancer Res 2002;62:5451-6. [PubMed: 12359752] 
[32]. Yan C, Jamaluddin MS, Aggarwal B, et al. Gene expression profiling identifies activating transcription factor 3 as a novel contributor to the proapoptotic effect of curcumin. Mol Cancer Ther 2005;4:233-41. [PubMed: 15713895]

[33]. Jung EM, Park JW, Choi KS, et al. Curcumin sensitizes tumor necrosis factor-related apoptosisinducing ligand (TRAIL)-mediated apoptosis through CHOP-independent DR5 upregulation. Carcinogenesis 2006;27:2008-17. [PubMed: 16613838]

[34]. Shishodia S, Singh T, Chaturvedi MM. Modulation of transcription factors by curcumin. Adv Exp Med Biol 2007;595:127-48. [PubMed: 17569208]

[35]. Chen A, Xu J. Activation of PPAR \{gamma $\}$ by curcumin inhibits Moser cell growth and mediates suppression of gene expression of cyclin D1 and EGFR. Am J Physiol Gastrointest Liver Physiol 2005;288:G447-56. [PubMed: 15486348]

[36]. Yang C, Zhang X, Fan H, et al. Curcumin upregulates transcription factor Nrf2, HO-1 expression and protects rat brains against focal ischemia. Brain Res 2009;1282:133-41. [PubMed: 19445907]

[37]. Hayden MS, Ghosh S. Shared principles in NF-kappaB signaling. Cell 2008;132:344-62. [PubMed: 18267068]

[38]. Hayden MS, West AP, Ghosh S. NF-kappaB and the immune response. Oncogene 2006;25:6758-80. [PubMed: 17072327]

[39]. Solt LA, May MJ. The IkappaB kinase complex: master regulator of NF-kappaB signaling. Immunol Res 2008;42:3-18. [PubMed: 18626576]

[40]. Verma IM, Stevenson JK, Schwarz EM, et al. Rel/NF-kappa B/I kappa B family: intimate tales of association and dissociation. Genes Dev 1995;9:2723-35. [PubMed: 7590248]

[41]. Pahl HL. Activators and target genes of Rel/NF-kappaB transcription factors. Oncogene 1999;18:6853-66. [PubMed: 10602461]

[42]. Sovak MA, Bellas RE, Kim DW, et al. Aberrant nuclear factor-kappaB/Rel expression and the pathogenesis of breast cancer. J Clin Invest 1997;100:2952-60. [PubMed: 9399940]

[43]. Lu T, Sathe SS, Swiatkowski SM, et al. Secretion of cytokines and growth factors as a general cause of constitutive NFkappaB activation in cancer. Oncogene 2004;23:2138-45. [PubMed: 14676835]

[44]. Wang W, Abbruzzese JL, Evans DB, et al. The nuclear factor-kappa B RelA transcription factor is constitutively activated in human pancreatic adenocarcinoma cells. Clin Cancer Res 1999;5:119-27. [PubMed: 9918209]

[45]. Jackson-Bernitsas DG, Ichikawa H, Takada Y, et al. Evidence that TNF-TNFR1-TRADDTRAF2-RIP-TAK1-IKK pathway mediates constitutive NF-kappaB activation and proliferation in human head and neck squamous cell carcinoma. Oncogene 2007;26:1385-97. [PubMed: 16953224]

[46]. Kordes U, Krappmann D, Heissmeyer V, et al. Transcription factor NF-kappaB is constitutively activated in acute lymphoblastic leukemia cells. Leukemia 2000;14:399-402. [PubMed: 10720133]

[47]. Yang J, Richmond A. Constitutive IkappaB kinase activity correlates with nuclear factor-kappaB activation in human melanoma cells. Cancer Res 2001;61:4901-9. [PubMed: 11406569]

[48]. Singh S, Aggarwal BB. Activation of transcription factor NF-kappa B is suppressed by curcumin (diferuloylmethane) [corrected]. J Biol Chem 1995;270:24995-5000. [PubMed: 7559628]

[49]. Aggarwal S, Takada Y, Singh S, et al. Inhibition of growth and survival of human head and neck squamous cell carcinoma cells by curcumin via modulation of nuclear factor-kappaB signaling. Int J Cancer 2004;111:679-92. [PubMed: 15252836]

[50]. Maillard I, Adler SH, Pear WS. Notch and the immune system. Immunity 2003;19:781-91. [PubMed: 14670296]

[51]. Mumm JS, Kopan R. Notch signaling: from the outside in. Dev Biol 2000;228:151-65. [PubMed: 11112321]

[52]. Karin M, Liu Z, Zandi E. AP-1 function and regulation. Curr Opin Cell Biol 1997;9:240-6. [PubMed: 9069263]

[53]. Vesely PW, Staber PB, Hoefler G, et al. Translational regulation mechanisms of AP-1 proteins. Mutat Res 2009;682:7-12. [PubMed: 19167516] 
[54]. Angel P, Imagawa M, Chiu R, et al. Phorbol ester-inducible genes contain a common cis element recognized by a TPA-modulated trans-acting factor. Cell 1987;49:729-39. [PubMed: 3034432]

[55]. Andreucci JJ, Grant D, Cox DM, et al. Composition and function of AP-1 transcription complexes during muscle cell differentiation. J Biol Chem 2002;277:16426-32. [PubMed: 11877423]

[56]. Pfarr CM, Mechta F, Spyrou G, et al. Mouse JunD negatively regulates fibroblast growth and antagonizes transformation by ras. Cell 1994;76:747-60. [PubMed: 8124713]

[57]. Bierhaus A, Zhang Y, Quehenberger P, et al. The dietary pigment curcumin reduces endothelial tissue factor gene expression by inhibiting binding of AP-1 to the DNA and activation of NFkappa B. Thromb Haemost 1997;77:772-82. [PubMed: 9134658]

[58]. Dickinson DA, Iles KE, Zhang H, et al. Curcumin alters EpRE and AP-1 binding complexes and elevates glutamate-cysteine ligase gene expression. Faseb J 2003;17:473-5. [PubMed: 12514113]

[59]. Kang ES, Kim GH, Kim HJ, et al. Nrf2 regulates curcumin-induced aldose reductase expression indirectly via nuclear factor-kappaB. Pharmacol Res 2008;58:15-21. [PubMed: 18588981]

[60]. Balogun E, Hoque M, Gong P, et al. Curcumin activates the haem oxygenase-1 gene via regulation of Nrf2 and the antioxidant-responsive element. Biochem J 2003;371:887-95. [PubMed: 12570874]

[61]. de Jong JS, van Diest PJ, van der Valk P, et al. Expression of growth factors, growth factor receptors and apoptosis related proteins in invasive breast cancer: relation to apoptotic rate. Breast Cancer Res Treat 2001;66:201-8. [PubMed: 11510691]

[62]. Elder JT, Fisher GJ, Lindquist PB, et al. Overexpression of transforming growth factor alpha in psoriatic epidermis. Science 1989;243:811-4. [PubMed: 2916128]

[63]. Elder LT, Klein SB, Tavakkol A, et al. Growth factor and proto-oncogene expression in psoriasis. J Invest Dermatol 1990;95:7S-9S.

[64]. Yarden Y, Sliwkowski M. Untangling the ErbB Signalling Network. Nat Rev Mol Cell Biol 2001;2:127-37. [PubMed: 11252954]

[65]. Scaltriti M, Baselga J. The Epidermal Growth Factor Receptor Pathway: A Model for Targeted Therapy. Clin Cancer Res 2006;12:5268-72. [PubMed: 17000658]

[66]. Burgess A, Cho H, Eigenbrot C, et al. An Open-and-Shut Case? Recent Insights into the Activation of EGF/ErbB Receptors. Molecular Cell 2003;12:541-52. [PubMed: 14527402]

[67]. Chen A, Xu J, Johnson A. Curcumin inhibits human colon cancer cell growth by suppressing gene expression of epidermal growth factor receptor through reducing the activity of the transcription factor Egr-1. Oncogene 2006;25:278-87. [PubMed: 16170359]

[68]. Lin S, Makino K, Xia W, et al. Nuclear localization of EGF receptor and its potential new role as a transcription factor. Nat Cell Biol 2001;3:802-8. [PubMed: 11533659]

[69]. Lo H, Hsu S, Ali-Seyed M, et al. Nuclear interaction of EGFR and STAT3 in the activation of the iNOS/NO pathway. Cancer Cell 2005;7:575-89. [PubMed: 15950906]

[70]. Hanada N, Lo H, Day C, et al. Co-regulation of B-Myb expression by E2F1 and EGF receptor. Molecular Carcinogenesis 2006;45:10-7. [PubMed: 16299810]

[71]. Ahmed K, Cao N, Li J. HER-2 and NF-kappaB as targets for therapy-resistant breast cancers. Anticancer Res 2006;26:4235-43. [PubMed: 17201139]

[72]. Astsaturov I, Cohen R, Harari P. Targeting epidermal growth factor receptor signaling in the treatment of head and neck cancer. Expert Review of Anticancer Therapy 2006;6:1179-93. [PubMed: 17020453]

[73]. Dancey J, Freidlin B. Targeting epidermal growth factor receptor--are we missing the mark? The Lancet 2003;362:62-4.

[74]. Korutla L, Cheung JY, Mendelsohn J, et al. Inhibition of ligand-induced activation of epidermal growth factor receptor tyrosine phosphorylation by curcumin. Carcinogenesis 1995;16:1741-5. [PubMed: 7634398]

[75]. Korutla L, Kumar R. Inhibitory effect of curcumin on epidermal growth factor receptor kinase activity in A431 cells. Biochim Biophys Acta 1994;1224:597-600. [PubMed: 7803521] 
[76]. Levi-Ari S, Starr A, Vexler A, et al. Inhibition of pancreatic and lung adenocarcinoma cell survival by curcumin is associated with increased apoptosis, down-regulation of COX-2 and EGFR and inhibition of Erk 1/2 activity. Anticancer Res 2006;26:4423-30. [PubMed: 17201164]

[77]. Hong RL, Spohn WH, Hung MC. Curcumin inhibits tyrosine kinase activity of p185neu and also depletes p185neu. Clin Cancer Res 1999;5:1884-91. [PubMed: 10430096]

[78]. Gasparini G. Biological and clinical role of angiogenesis in breast cancer. Breast Cancer Res Treat 1995;36:103-7. [PubMed: 8534859]

[79]. Strimpakos AS, Sharma RA. Curcumin: preventive and therapeutic properties in laboratory studies and clinical trials. Antioxid Redox Signal 2008;10:511-45. [PubMed: 18370854]

[80]. Herynk MH, Fuqua SA. Estrogen receptors in resistance to hormone therapy. Adv Exp Med Biol 2007;608:130-43. [PubMed: 17993238]

[81]. Verma SP, Goldin BR, Lin PS. The inhibition of the estrogenic effects of pesticides and environmental chemicals by curcumin and isoflavonoids. Environ Health Perspect 1998;106:807-12. [PubMed: 9831541]

[82]. Hsing AW, Reichardt JK, Stanczyk FZ. Hormones and prostate cancer: current perspectives and future directions. Prostate 2002;52:213-35. [PubMed: 12111697]

[83]. Ikonen T, Palvimo JJ, Kallio PJ, et al. Stimulation of androgen-regulated transactivation by modulators of protein phosphorylation. Endocrinology 1994;135:1359-66. [PubMed: 7925097]

[84]. Nazareth LV, Weigel NL. Activation of the human androgen receptor through a protein kinase A signaling pathway. J Biol Chem 1996;271:19900-7. [PubMed: 8702703]

[85]. Culig Z, Hobisch A, Cronauer MV, et al. Androgen receptor activation in prostatic tumor cell lines by insulin-like growth factor-I, keratinocyte growth factor, and epidermal growth factor. Cancer Res 1994;54:5474-8. [PubMed: 7522959]

[86]. Sato N, Sadar MD, Bruchovsky N, et al. Androgenic induction of prostate-specific antigen gene is repressed by protein-protein interaction between the androgen receptor and AP-1/c-Jun in the human prostate cancer cell line LNCaP. J Biol Chem 1997;272:17485-94. [PubMed: 9211894]

[87]. Fronsdal K, Engedal N, Slagsvold T, et al. CREB binding protein is a coactivator for the androgen receptor and mediates cross-talk with AP-1. J Biol Chem 1998;273:31853-9. [PubMed: 9822653]

[88]. Palvimo JJ, Reinikainen P, Ikonen T, et al. Mutual transcriptional interference between RelA and androgen receptor. J Biol Chem 1996;271:24151-6. [PubMed: 8798655]

[89]. Nakamura K, Yasunaga Y, Segawa T, et al. Curcumin down-regulates AR gene expression and activation in prostate cancer cell lines. Int J Oncol 2002;21:825-30. [PubMed: 12239622]

[90]. Muller A, Homey B, Soto H, et al. Involvement of chemokine receptors in breast cancer metastasis. Nature 2001;410:50-6. [PubMed: 11242036]

[91]. Ghobrial IM, Bone ND, Stenson MJ, et al. Expression of the chemokine receptors CXCR4 and CCR7 and disease progression in B-cell chronic lymphocytic leukemia/ small lymphocytic lymphoma. Mayo Clin Proc 2004;79:318-25. [PubMed: 15008605]

[92]. Nanki T, Hayashida K, El-Gabalawy HS, et al. Stromal cell-derived factor-1-CXC chemokine receptor 4 interactions play a central role in $\mathrm{CD} 4+\mathrm{T}$ cell accumulation in rheumatoid arthritis synovium. J Immunol 2000;165:6590-8. [PubMed: 11086103]

[93]. Sameermahmood Z, Balasubramanyam M, Saravanan T, et al. Curcumin modulates SDF-1alpha/ CXCR4-induced migration of human retinal endothelial cells (HRECs). Invest Ophthalmol Vis Sci 2008;49:3305-11. [PubMed: 18660423]

[94]. Skommer J, Wlodkowic D, Pelkonen J. Gene-expression profiling during curcumin-induced apoptosis reveals downregulation of CXCR4. Exp Hematol 2007;35:84-95. [PubMed: 17198877]

[95]. Hasmeda M, Polya GM. Inhibition of cyclic AMP-dependent protein kinase by curcumin. Phytochemistry 1996;42:599-605. [PubMed: 8768315]

[96]. Jurrmann N, Brigelius-Flohe R, Bol GF. Curcumin blocks interleukin-1 (IL-1) signaling by inhibiting the recruitment of the IL-1 receptor-associated kinase IRAK in murine thymoma EL-4 cells. J Nutr 2005;135:1859-64. [PubMed: 16046709] 
[97]. Kim GY, Kim KH, Lee SH, et al. Curcumin inhibits immunostimulatory function of dendritic cells: MAPKs and translocation of NF-kappa B as potential targets. J Immunol 2005;174:811624. [PubMed: 15944320]

[98]. Rafiee P, Nelson VM, Manley S, et al. Effect of curcumin on acidic pH-induced expression of IL-6 and IL-8 in human esophageal epithelial cells (HET-1A): role of PKC, MAPKs, and NFkappaB. Am J Physiol Gastrointest Liver Physiol 2009;296:G388-98. [PubMed: 19074641]

[99]. Johnson SM, Gulhati P, Arrieta I, et al. Curcumin inhibits proliferation of colorectal carcinoma by modulating Akt/mTOR signaling. Anticancer Res 2009;29:3185-90. [PubMed: 19661333]

[100]. Shinojima N, Yokoyama T, Kondo Y, et al. Roles of the Akt/mTOR/p70S6K and ERK1/2 signaling pathways in curcumin-induced autophagy. Autophagy 2007;3:635-7. [PubMed: 17786026]

[101]. Kizhakkayil J, Thayyullathil F, Chathoth S, et al. Modulation of curcumin-induced Akt phosphorylation and apoptosis by PI3K inhibitor in MCF-7 cells. Biochem Biophys Res Commun.

[102]. Gururajan M, Dasu T, Shahidain S, et al. Spleen tyrosine kinase (Syk), a novel target of curcumin, is required for B lymphoma growth. J Immunol 2007;178:111-21. [PubMed: 17182546]

[103]. Hay N, Sonenberg N. Upstream and downstream of mTOR. Genes Dev 2004;18:1926-45. [PubMed: 15314020]

[104]. Kim D, Sarbassov D, Ali S, et al. mTOR interacts with raptor to form a nutrient-sensitive complex that signals to the cell growth machinery. Cell 2002;110:163-75. [PubMed: 12150925]

[105]. Grewe M, Gansauge F, Schmid R, et al. Regulation of Cell Growth and Cyclin D1 Expression by the Constitutively Active FRAP-p70s6K Pathway in Human Pancreatic Cancer Cells. Cancer Res 1999;59:3581-87. [PubMed: 10446965]

[106]. Liu L, Li F, Cardelli J, et al. Rapamycin inhibits cell motility by suppression of mTORmediated S6K1 and 4E-BP1 pathways. Oncogene 2006;25:7029-40. [PubMed: 16715128]

[107]. Huang S, Shu L, Easton J, et al. Inhibition of mammalian target of rapamycin activates apoptosis signal-regulating kinase 1 signaling by suppressing protein phosphatase 5 activity. $\mathrm{J}$ Biol Chem 2004;279:36490-96. [PubMed: 15218033]

[108]. Wullschleger S, Loewith R, Hall M. TOR Signaling in Growth and Metabolism. Cell 2006;124:471-84. [PubMed: 16469695]

[109]. Tsang C, Bertram P, Ai W, et al. Chromatin-mediated regulation of nucleolar structure and RNA Pol I localization by TOR. EMBO J 2003;22:6045-56. [PubMed: 14609951]

[110]. Mayer, C.; Grummt, I. Ribosome biogenesis and cell growth: mTOR coordinates transcription by all three classes of nuclear RNA polymerases; 2006. p. 6384-91.

[111]. Tokunaga C, Yoshino K, Yonezawa K. mTOR integrates amino-acid and energy-sensing pathways. Biochem Biophys Res Commun 2004;313:443-46. [PubMed: 14684182]

[112]. Kim D, Sarbassov D, Ali S, et al. GbetaL, a positive regulator of the rapamycin-sensitive pathway required for the nutrient-sensitive interaction between raptor and mTOR. Mol Cell 2003;11:895-904. [PubMed: 12718876]

[113]. Sarbassov D, Sabatini D. Redox Regulation of the Nutrient-sensitive Raptor-mTOR Pathway and Complex. J Biol Chem 2005;280:39505-09. [PubMed: 16183647]

[114]. Frias MA, Thoreen CC, Jaffe JD, et al. mSin1 is necessary for Akt/PKB phosphorylation, and its isoforms define three distinct mTORC2s. Curr Biol 2006;16:1865-70. [PubMed: 16919458]

[115]. Beevers CS, Li F, Liu L, et al. Curcumin inhibits the mammalian target of rapamycin-mediated signaling pathways in cancer cells. Int J Cancer 2006;119:757-64. [PubMed: 16550606]

[116]. Chakraborty S, Mohiyuddin SM, Gopinath KS, et al. Involvement of TSC genes and differential expression of other members of the mTOR signaling pathway in oral squamous cell carcinoma. BMC Cancer 2008;8:163. [PubMed: 18538015]

[117]. Darb-Esfahani S, Faggad A, Noske A, et al. Phospho-mTOR and phospho-4EBP1 in endometrial adenocarcinoma: association with stage and grade in vivo and link with response to rapamycin treatment in vitro. J Cancer Res Clin Oncol 2009;135:933-41. [PubMed: 19107520]

[118]. Rosenwald IB. The role of translation in neoplastic transformation from a pathologist's point of view. Oncogene 2004;23:3230-47. [PubMed: 15094773] 
[119]. Ekstrand AI, Jonsson M, Lindblom A, et al. Frequent alterations of the PI3K/AKT/mTOR pathways in hereditary nonpolyposis colorectal cancer. Fam Cancer. 2009

[120]. Chan JA, Zhang H, Roberts PS, et al. Pathogenesis of tuberous sclerosis subependymal giant cell astrocytomas: biallelic inactivation of TSC1 or TSC2 leads to mTOR activation. J Neuropathol Exp Neurol 2004;63:1236-42. [PubMed: 15624760]

[121]. Riemenschneider MJ, Betensky RA, Pasedag SM, et al. AKT activation in human glioblastomas enhances proliferation via TSC2 and S6 kinase signaling. Cancer Res 2006;66:5618-23. [PubMed: 16740698]

[122]. Hara K, Maruki Y, Long X, et al. Raptor, a binding partner of target of rapamycin (TOR), mediates TOR action. Cell 2002;110:177-89. [PubMed: 12150926]

[123]. Kim DH, Sarbassov DD, Ali SM, et al. GbetaL, a positive regulator of the rapamycin-sensitive pathway required for the nutrient-sensitive interaction between raptor and mTOR. Mol Cell 2003;11:895-904. [PubMed: 12718876]

[124]. Sancak Y, Thoreen CC, Peterson TR, et al. PRAS40 is an insulin-regulated inhibitor of the mTORC1 protein kinase. Mol Cell 2007;25:903-15. [PubMed: 17386266]

[125]. Peterson TR, Laplante M, Thoreen CC, et al. DEPTOR is an mTOR inhibitor frequently overexpressed in multiple myeloma cells and required for their survival. Cell 2009;137:873-86. [PubMed: 19446321]

[126]. Fingar DC, Blenis J. Target of rapamycin (TOR): an integrator of nutrient and growth factor signals and coordinator of cell growth and cell cycle progression. Oncogene 2004;23:3151-71. [PubMed: 15094765]

[127]. Sarbassov DD, Ali SM, Kim DH, et al. Rictor, a novel binding partner of mTOR, defines a rapamycin-insensitive and raptor-independent pathway that regulates the cytoskeleton. Curr Biol 2004;14:1296-302. [PubMed: 15268862]

[128]. Pearce LR, Huang X, Boudeau J, et al. Identification of Protor as a novel Rictor-binding component of mTOR complex-2. Biochem J 2007;405:513-22. [PubMed: 17461779]

[129]. Woo SY, Kim DH, Jun CB, et al. PRR5, a novel component of mTOR complex 2, regulates platelet-derived growth factor receptor beta expression and signaling. J Biol Chem 2007;282:25604-12. [PubMed: 17599906]

[130]. Martin J, Masri J, Bernath A, et al. Hsp70 associates with Rictor and is required for mTORC2 formation and activity. Biochem Biophys Res Commun 2008;372:578-83. [PubMed: 18505677]

[131]. Hresko RC, Mueckler M. mTOR.RICTOR is the Ser473 kinase for Akt/protein kinase B in 3T3L1 adipocytes. J Biol Chem 2005;280:40406-16. [PubMed: 16221682]

[132]. Sarbassov DD, Guertin DA, Ali SM, et al. Phosphorylation and regulation of Akt/PKB by the rictor-mTOR complex. Science 2005;307:1098-101. [PubMed: 15718470]

[133]. Jacinto E, Loewith R, Schmidt A, et al. Mammalian TOR complex 2 controls the actin cytoskeleton and is rapamycin insensitive. Nat Cell Biol 2004;6:1122-8. [PubMed: 15467718]

[134]. Li M, Zhang Z, Hill DL, et al. Curcumin, a dietary component, has anticancer, chemosensitization, and radiosensitization effects by down-regulating the MDM2 oncogene through the PI3K/mTOR/ETS2 pathway. Cancer Res 2007;67:1988-96. [PubMed: 17332326]

[135]. Beevers CS, Chen L, Liu L, et al. Curcumin disrupts the Mammalian target of rapamycin-raptor complex. Cancer Res 2009;69:1000-8. [PubMed: 19176385]

[136]. Pearson G, Robinson F, Gibson T Beers, et al. Mitogen-activated protein (MAP) kinase pathways: regulation and physiological functions. Endocr Rev 2001;22:153-83. [PubMed: 11294822]

[137]. Chen YR, Tan TH. Inhibition of the c-Jun N-terminal kinase (JNK) signaling pathway by curcumin. Oncogene 1998;17:173-8. [PubMed: 9674701]

[138]. Squires MS, Hudson EA, Howells L, et al. Relevance of mitogen activated protein kinase (MAPK) and phosphotidylinositol-3-kinase/protein kinase B (PI3K/PKB) pathways to induction of apoptosis by curcumin in breast cells. Biochem Pharmacol 2003;65:361-76. [PubMed: 12527329]

[139]. Weir NM, Selvendiran K, Kutala VK, et al. Curcumin induces G2/M arrest and apoptosis in cisplatin-resistant human ovarian cancer cells by modulating Akt and p38 MAPK. Cancer Biol Ther 2007;6:178-84. [PubMed: 17218783] 
[140]. Camacho-Barquero L, Villegas I, Sanchez-Calvo JM, et al. Curcumin, a Curcuma longa constituent, acts on MAPK p38 pathway modulating COX-2 and iNOS expression in chronic experimental colitis. Int Immunopharmacol 2007;7:333-42. [PubMed: 17276891]

[141]. Munford RS, Pugin J. Normal responses to injury prevent systemic inflammation and can be immunosuppressive. Am J Respir Crit Care Med 2001;163:316-21. [PubMed: 11179099]

[142]. Baeuerle PA, Henkel T. Function and activation of NF-kappa B in the immune system. Annu Rev Immunol 1994;12:141-79. [PubMed: 8011280]

[143]. Tak PP, Firestein GS. NF-kappaB: a key role in inflammatory diseases. J Clin Invest 2001;107:7-11. [PubMed: 11134171]

[144]. Chen D, Nie M, Fan MW, et al. Anti-inflammatory activity of curcumin in macrophages stimulated by lipopolysaccharides from Porphyromonas gingivalis. Pharmacology 2008;82:264 9. [PubMed: 18849645]

[145]. Abe Y, Hashimoto S, Horie T. Curcumin inhibition of inflammatory cytokine production by human peripheral blood monocytes and alveolar macrophages. Pharmacol Res 1999;39:41-7. [PubMed: 10051376]

[146]. Srimal RC, Dhawan BN. Pharmacology of diferuloyl methane (curcumin), a non-steroidal antiinflammatory agent. J Pharm Pharmacol 1973;25:447-52. [PubMed: 4146582]

[147]. Locksley RM, Killeen N, Lenardo MJ. The TNF and TNF receptor superfamilies: integrating mammalian biology. Cell 2001;104:487-501. [PubMed: 11239407]

[148]. Aggarwal BB, Shishodia S, Takada Y, et al. TNF blockade: an inflammatory issue. Ernst Schering Res Found Workshop 2006:161-86. [PubMed: 16331857]

[149]. Kuhad A, Chopra K. Curcumin attenuates diabetic encephalopathy in rats: behavioral and biochemical evidences. Eur J Pharmacol 2007;576:34-42. [PubMed: 17822693]

[150]. Fu Y, Zheng S, Lin J, et al. Curcumin protects the rat liver from CCl4-caused injury and fibrogenesis by attenuating oxidative stress and suppressing inflammation. Mol Pharmacol 2008;73:399-409. [PubMed: 18006644]

[151]. Kumar A, Dhawan S, Hardegen NJ, et al. Curcumin (Diferuloylmethane) inhibition of tumor necrosis factor (TNF)-mediated adhesion of monocytes to endothelial cells by suppression of cell surface expression of adhesion molecules and of nuclear factor-kappaB activation. Biochem Pharmacol 1998;55:775-83. [PubMed: 9586949]

[152]. Dinarello CA. The paradox of pro-inflammatory cytokines in cancer. Cancer Metastasis Rev 2006;25:307-13. [PubMed: 17029030]

[153]. Cho JW, Lee KS, Kim CW. Curcumin attenuates the expression of IL-1beta, IL-6, and TNFalpha as well as cyclin E in TNF-alpha-treated HaCaT cells; NF-kappaB and MAPKs as potential upstream targets. Int J Mol Med 2007;19:469-74. [PubMed: 17273796]

[154]. Ranjan D, Chen C, Johnston TD, et al. Curcumin inhibits mitogen stimulated lymphocyte proliferation, NFkappaB activation, and IL-2 signaling. J Surg Res 2004;121:171-7. [PubMed: 15501456]

[155]. Kobayashi T, Hashimoto S, Horie T. Curcumin inhibition of Dermatophagoides farinea-induced interleukin-5 (IL-5) and granulocyte macrophage-colony stimulating factor (GM-CSF) production by lymphocytes from bronchial asthmatics. Biochem Pharmacol 1997;54:819-24. [PubMed: 9353136]

[156]. Cohen AN, Veena MS, Srivatsan ES, et al. Suppression of interleukin 6 and 8 production in head and neck cancer cells with curcumin via inhibition of Ikappa beta kinase. Arch Otolaryngol Head Neck Surg 2009;135:190-7. [PubMed: 19221248]

[157]. Wang X, Wang Q, Ives KL, et al. Curcumin inhibits neurotensin-mediated interleukin-8 production and migration of HCT116 human colon cancer cells. Clin Cancer Res 2006;12:534655. [PubMed: 17000667]

[158]. Fahey AJ, Robins R Adrian, Constantinescu CS. Curcumin modulation of IFN-beta and IL-12 signalling and cytokine induction in human T cells. J Cell Mol Med 2007;11:1129-37. [PubMed: 17979888]

[159]. Grandjean-Laquerriere A, Antonicelli F, Gangloff SC, et al. UVB-induced IL-18 production in human keratinocyte cell line NCTC 2544 through NF-kappaB activation. Cytokine 2007;37:7683. [PubMed: 17399992] 
[160]. Bharti AC, Donato N, Aggarwal BB. Curcumin (diferuloylmethane) inhibits constitutive and IL-6-inducible STAT3 phosphorylation in human multiple myeloma cells. J Immunol 2003;171:3863-71. [PubMed: 14500688]

[161]. Bachmeier BE, Mohrenz IV, Mirisola V, et al. Curcumin downregulates the inflammatory cytokines CXCL1 and -2 in breast cancer cells via NFkappaB. Carcinogenesis 2008;29:779-89. [PubMed: 17999991]

[162]. Lim JH, Kwon TK. Curcumin inhibits phorbol myristate acetate (PMA)-induced MCP-1 expression by inhibiting ERK and NF-kappaB transcriptional activity. Food Chem Toxicol 48:47-52. [PubMed: 19766691]

[163]. Subbaramaiah K, Dannenberg AJ. Cyclooxygenase 2: a molecular target for cancer prevention and treatment. Trends Pharmacol Sci 2003;24:96-102. [PubMed: 12559775]

[164]. Seibert K, Masferrer JL. Role of inducible cyclooxygenase (COX-2) in inflammation. Receptor 1994;4:17-23. [PubMed: 8038702]

[165]. Tiano HF, Loftin CD, Akunda J, et al. Deficiency of either cyclooxygenase (COX)-1 or COX-2 alters epidermal differentiation and reduces mouse skin tumorigenesis. Cancer Res 2002;62:3395-401. [PubMed: 12067981]

[166]. Jacoby RF, Seibert K, Cole CE, et al. The cyclooxygenase-2 inhibitor celecoxib is a potent preventive and therapeutic agent in the min mouse model of adenomatous polyposis. Cancer Res 2000;60:5040-4. [PubMed: 11016626]

[167]. Oshima M, Murai N, Kargman S, et al. Chemoprevention of intestinal polyposis in the Apcdelta716 mouse by rofecoxib, a specific cyclooxygenase- 2 inhibitor. Cancer Res 2001;61:1733-40. [PubMed: 11245490]

[168]. Chulada PC, Thompson MB, Mahler JF, et al. Genetic disruption of Ptgs-1, as well as Ptgs-2, reduces intestinal tumorigenesis in Min mice. Cancer Res 2000;60:4705-8. [PubMed: 10987272]

[169]. Chun KS, Keum YS, Han SS, et al. Curcumin inhibits phorbol ester-induced expression of cyclooxygenase- 2 in mouse skin through suppression of extracellular signal-regulated kinase activity and NF-kappaB activation. Carcinogenesis 2003;24:1515-24. [PubMed: 12844482]

[170]. Kunnumakkara AB, Guha S, Krishnan S, et al. Curcumin potentiates antitumor activity of gemcitabine in an orthotopic model of pancreatic cancer through suppression of proliferation, angiogenesis, and inhibition of nuclear factor-kappaB-regulated gene products. Cancer Res 2007;67:3853-61. [PubMed: 17440100]

[171]. Yoysungnoen P, Wirachwong P, Bhattarakosol P, et al. Effects of curcumin on tumor angiogenesis and biomarkers, COX-2 and VEGF, in hepatocellular carcinoma cell-implanted nude mice. Clin Hemorheol Microcirc 2006;34:109-15. [PubMed: 16543625]

[172]. Zhang F, Altorki NK, Mestre JR, et al. Curcumin inhibits cyclooxygenase-2 transcription in bile acid- and phorbol ester-treated human gastrointestinal epithelial cells. Carcinogenesis 1999;20:445-51. [PubMed: 10190560]

[173]. Lee YK, Park SY, Kim YM, et al. Regulatory effect of the AMPK-COX-2 signaling pathway in curcumin-induced apoptosis in HT-29 colon cancer cells. Ann N Y Acad Sci 2009;1171:489-94. [PubMed: 19723094]

[174]. Lee YK, Lee WS, Hwang JT, et al. Curcumin exerts antidifferentiation effect through AMPKalpha-PPAR-gamma in 3T3-L1 adipocytes and antiproliferatory effect through AMPKalpha-COX-2 in cancer cells. J Agric Food Chem 2009;57:305-10. [PubMed: 19093868]

[175]. Tenhunen R, Marver HS, Schmid R. The enzymatic conversion of heme to bilirubin by microsomal heme oxygenase. Proc Natl Acad Sci U S A 1968;61:748-55. [PubMed: 4386763]

[176]. Otterbein LE, Kolls JK, Mantell LL, et al. Exogenous administration of heme oxygenase-1 by gene transfer provides protection against hyperoxia-induced lung injury. J Clin Invest 1999;103:1047-54. [PubMed: 10194478]

[177]. Amersi F, Buelow R, Kato H, et al. Upregulation of heme oxygenase-1 protects genetically fat Zucker rat livers from ischemia/reperfusion injury. J Clin Invest 1999;104:1631-9. [PubMed: 10587527]

[178]. Vogt BA, Shanley TP, Croatt A, et al. Glomerular inflammation induces resistance to tubular injury in the rat. A novel form of acquired, heme oxygenase-dependent resistance to renal injury. J Clin Invest 1996;98:2139-45. [PubMed: 8903334] 
[179]. Tamion F, Richard V, Bonmarchand G, et al. Induction of heme-oxygenase-1 prevents the systemic responses to hemorrhagic shock. Am J Respir Crit Care Med 2001;164:1933-8. [PubMed: 11734449]

[180]. Gaedeke J, Noble NA, Border WA. Curcumin blocks fibrosis in anti-Thy 1 glomerulonephritis through up-regulation of heme oxygenase 1. Kidney Int 2005;68:2042-9. [PubMed: 16221204]

[181]. McNally SJ, Harrison EM, Ross JA, et al. Curcumin induces heme oxygenase 1 through generation of reactive oxygen species, p38 activation and phosphatase inhibition. Int J Mol Med 2007;19:165-72. [PubMed: 17143561]

[182]. Mizushina Y, Dairaku I, Yanaka N, et al. Inhibitory action of polyunsaturated fatty acids on IMP dehydrogenase. Biochimie 2007;89:581-90. [PubMed: 17383068]

[183]. Collart FR, Chubb CB, Mirkin BL, et al. Increased inosine-5'-phosphate dehydrogenase gene expression in solid tumor tissues and tumor cell lines. Cancer Res 1992;52:5826-8. [PubMed: 1356621]

[184]. Jayaram HN, Cooney DA, Grusch M, et al. Consequences of IMP dehydrogenase inhibition, and its relationship to cancer and apoptosis. Curr Med Chem 1999;6:561-74. [PubMed: 10390601]

[185]. Dairaku I, Han Y, Yanaka N, et al. Inhibitory effect of curcumin on IMP dehydrogenase, the target for anticancer and antiviral chemotherapy agents. Biosci Biotechnol Biochem 74:185-7. [PubMed: 20057137]

[186]. Chen YS, Ho CC, Cheng KC, et al. Curcumin inhibited the arylamines N-acetyltransferase activity, gene expression and DNA adduct formation in human lung cancer cells (A549). Toxicol In Vitro 2003;17:323-33. [PubMed: 12781211]

[187]. Sharma D, Sethi P, Hussain E, et al. Curcumin counteracts the aluminium-induced ageingrelated alterations in oxidative stress, $\mathrm{Na}+\mathrm{K}+\mathrm{ATPase}$ and protein kinase $\mathrm{C}$ in adult and old rat brain regions. Biogerontology 2009;10:489-502. [PubMed: 19020987]

[188]. Shimizu S, Jareonkitmongkol S, Kawashima H, et al. Inhibitory effect of curcumin on fatty acid desaturation in Mortierella alpina 1S-4 and rat liver microsomes. Lipids 1992;27:509-12. [PubMed: 1453881]

[189]. Kohl NE, Omer CA, Conner MW, et al. Inhibition of farnesyltransferase induces regression of mammary and salivary carcinomas in ras transgenic mice. Nat Med 1995;1:792-7. [PubMed: 7585182]

[190]. Hong J, Bose M, Ju J, et al. Modulation of arachidonic acid metabolism by curcumin and related beta-diketone derivatives: effects on cytosolic phospholipase A(2), cyclooxygenases and 5lipoxygenase. Carcinogenesis 2004;25:1671-9. [PubMed: 15073046]

[191]. Mun SH, Kim HS, Kim JW, et al. Oral administration of curcumin suppresses production of matrix metalloproteinase (MMP)-1 and MMP-3 to ameliorate collagen-induced arthritis: inhibition of the PKCdelta/JNK/c-Jun pathway. J Pharmacol Sci 2009;111:13-21. [PubMed: 19763044]

[192]. Swarnakar S, Paul S. Curcumin arrests endometriosis by downregulation of matrix metalloproteinase-9 activity. Indian J Biochem Biophys 2009;46:59-65. [PubMed: 19374255]

[193]. Lin SS, Lai KC, Hsu SC, et al. Curcumin inhibits the migration and invasion of human A549 lung cancer cells through the inhibition of matrix metalloproteinase- 2 and -9 and Vascular Endothelial Growth Factor (VEGF). Cancer Lett 2009;285:127-33. [PubMed: 19477063]

[194]. Tsvetkov P, Asher G, Reiss V, et al. Inhibition of NAD(P)H:quinone oxidoreductase 1 activity and induction of 553 degradation by the natural phenolic compound curcumin. Proc Natl Acad Sci U S A 2005;102:5535-40. [PubMed: 15809436]

[195]. Liao YF, Hung HC, Hour TC, et al. Curcumin induces apoptosis through an ornithine decarboxylase-dependent pathway in human promyelocytic leukemia HL-60 cells. Life Sci 2008;82:367-75. [PubMed: 18187158]

[196]. Okazaki Y, Iqbal M, Okada S. Suppressive effects of dietary curcumin on the increased activity of renal ornithine decarboxylase in mice treated with a renal carcinogen, ferric nitrilotriacetate. Biochim Biophys Acta 2005;1740:357-66. [PubMed: 15949703] 
[197]. Chakraborty, S Mukherjee Nee; Ghosh, U.; Bhattacharyya, NP., et al. Curcumin-induced apoptosis in human leukemia cell HL-60 is associated with inhibition of telomerase activity. Mol Cell Biochem 2007;297:31-9. [PubMed: 17096185]

[198]. Lee JH, Chung IK. Curcumin inhibits nuclear localization of telomerase by dissociating the Hsp90 co-chaperone p23 from hTERT. Cancer Lett. 2009

[199]. Pauff JM, Hille R. Inhibition studies of bovine xanthine oxidase by luteolin, silibinin, quercetin, and curcumin. J Nat Prod 2009;72:725-31. [PubMed: 19388706]

[200]. Shen L, Ji HF. Insights into the inhibition of xanthine oxidase by curcumin. Bioorg Med Chem Lett 2009;19:5990-3. [PubMed: 19800788]

[201]. Balamurugan AN, Akhov L, Selvaraj G, et al. Induction of antioxidant enzymes by curcumin and its analogues in human islets: implications in transplantation. Pancreas 2009;38:454-60. [PubMed: 19188863]

[202]. Kim HY, Park EJ, Joe EH, et al. Curcumin suppresses Janus kinase-STAT inflammatory signaling through activation of Src homology 2 domain-containing tyrosine phosphatase 2 in brain microglia. J Immunol 2003;171:6072-9. [PubMed: 14634121]

[203]. Elangbam CS, Qualls CW Jr. Dahlgren RR. Cell adhesion molecules--update. Vet Pathol 1997;34:61-73. [PubMed: 9150551]

[204]. Bruijn JA, de Heer E. Adhesion molecules in renal diseases. Lab Invest 1995;72:387-94. [PubMed: 7723276]

[205]. Haapasalmi K, Makela M, Oksala O, et al. Expression of epithelial adhesion proteins and integrins in chronic inflammation. Am J Pathol 1995;147:193-206. [PubMed: 7541610]

[206]. Rajan S, Ye J, Bai S, et al. NF-kappaB, but not p38 MAP kinase, is required for TNF-alphainduced expression of cell adhesion molecules in endothelial cells. J Cell Biochem 2008;105:477-86. [PubMed: 18613029]

[207]. Binion DG, Heidemann J, Li MS, et al. Vascular cell adhesion molecule-1 expression in human intestinal microvascular endothelial cells is regulated by PI 3-kinase/Akt/MAPK/NF-kappaB: inhibitory role of curcumin. Am J Physiol Gastrointest Liver Physiol 2009;297:G259-68. [PubMed: 19520742]

[208]. Milner R, Campbell IL. The integrin family of cell adhesion molecules has multiple functions within the CNS. J Neurosci Res 2002;69:286-91. [PubMed: 12125070]

[209]. Ray S, Chattopadhyay N, Mitra A, et al. Curcumin exhibits antimetastatic properties by modulating integrin receptors, collagenase activity, and expression of Nm23 and E-cadherin. J Environ Pathol Toxicol Oncol 2003;22:49-58. [PubMed: 12678405]

[210]. Kim HI, Huang H, Cheepala S, et al. Curcumin inhibition of integrin (alpha6beta4)-dependent breast cancer cell motility and invasion. Cancer Prev Res (Phila Pa) 2008;1:385-91.

[211]. Burz C, Berindan-Neagoe I, Balacescu O, et al. Apoptosis in cancer: key molecular signaling pathways and therapy targets. Acta Oncol 2009;48:811-21. [PubMed: 19513886]

[212]. Singh N, Anand S. Apoptosis in health and disease. Indian J Physiol Pharmacol 1995;39:91-4. [PubMed: 7649613]

[213]. Jee SH, Shen SC, Tseng CR, et al. Curcumin induces a p53-dependent apoptosis in human basal cell carcinoma cells. J Invest Dermatol 1998;111:656-61. [PubMed: 9764849]

[214]. Huang MT, Wang ZY, Georgiadis CA, et al. Inhibitory effects of curcumin on tumor initiation by benzo[a]pyrene and 7,12-dimethylbenz[a]anthracene. Carcinogenesis 1992;13:2183-6. [PubMed: 1423891]

[215]. Conney AH, Lysz T, Ferraro T, et al. Inhibitory effect of curcumin and some related dietary compounds on tumor promotion and arachidonic acid metabolism in mouse skin. Adv Enzyme Regul 1991;31:385-96. [PubMed: 1908616]

[216]. Huang MT, Smart RC, Wong CQ, et al. Inhibitory effect of curcumin, chlorogenic acid, caffeic acid, and ferulic acid on tumor promotion in mouse skin by 12-O-tetradecanoylphorbol-13acetate. Cancer Res 1988;48:5941-6. [PubMed: 3139287]

[217]. Odot J, Albert P, Carlier A, et al. In vitro and in vivo anti-tumoral effect of curcumin against melanoma cells. Int J Cancer 2004;111:381-7. [PubMed: 15221965] 
[218]. Ramachandran C, Rodriguez S, Ramachandran R, et al. Expression profiles of apoptotic genes induced by curcumin in human breast cancer and mammary epithelial cell lines. Anticancer Res 2005;25:3293-302. [PubMed: 16101141]

[219]. Shankar S, Chen Q, Sarva K, et al. Curcumin enhances the apoptosis-inducing potential of TRAIL in prostate cancer cells: molecular mechanisms of apoptosis, migration and angiogenesis. J Mol Signal 2007;2:10. [PubMed: 17916240]

[220]. Bae JH, Park JW, Kwon TK. Ruthenium red, inhibitor of mitochondrial Ca2+ uniporter, inhibits curcumin-induced apoptosis via the prevention of intracellular $\mathrm{Ca} 2+$ depletion and cytochrome $\mathrm{c}$ release. Biochem Biophys Res Commun 2003;303:1073-9. [PubMed: 12684045]

[221]. Anto RJ, Mukhopadhyay A, Denning K, et al. Curcumin (diferuloylmethane) induces apoptosis through activation of caspase- 8 , BID cleavage and cytochrome c release: its suppression by ectopic expression of Bcl-2 and Bcl-xl. Carcinogenesis 2002;23:143-50. [PubMed: 11756235]

[222]. Bharti AC, Donato N, Singh S, et al. Curcumin (diferuloylmethane) down-regulates the constitutive activation of nuclear factor-kappa B and IkappaBalpha kinase in human multiple myeloma cells, leading to suppression of proliferation and induction of apoptosis. Blood 2003;101:1053-62. [PubMed: 12393461]

[223]. Shishodia S, Amin HM, Lai R, et al. Curcumin (diferuloylmethane) inhibits constitutive NFkappaB activation, induces G1/S arrest, suppresses proliferation, and induces apoptosis in mantle cell lymphoma. Biochem Pharmacol 2005;70:700-13. [PubMed: 16023083]

[224]. Bush JA, Cheung KJ Jr. Li G. Curcumin induces apoptosis in human melanoma cells through a Fas receptor/caspase-8 pathway independent of p53. Exp Cell Res 2001;271:305-14. [PubMed: 11716543]

[225]. Kastan MB, Canman CE, Leonard CJ. P53, cell cycle control and apoptosis: implications for cancer. Cancer Metastasis Rev 1995;14:3-15. [PubMed: 7606818]

[226]. el-Deiry WS, Tokino T, Velculescu VE, et al. WAF1, a potential mediator of $\mathrm{p} 53$ tumor suppression. Cell 1993;75:817-25. [PubMed: 8242752]

[227]. Basu A, Haldar S. The relationship between BcI2, Bax and p53: consequences for cell cycle progression and cell death. Mol Hum Reprod 1998;4:1099-109. [PubMed: 9872359]

[228]. Liontas A, Yeger H. Curcumin and resveratrol induce apoptosis and nuclear translocation and activation of p53 in human neuroblastoma. Anticancer Res 2004;24:987-98. [PubMed: 15161054]

[229]. Choudhuri T, Pal S, Das T, et al. Curcumin selectively induces apoptosis in deregulated cyclin D1-expressed cells at $\mathrm{G} 2$ phase of cell cycle in a p53-dependent manner. J Biol Chem 2005;280:20059-68. [PubMed: 15738001]

[230]. Liu E, Wu J, Cao W, et al. Curcumin induces G2/M cell cycle arrest in a p53-dependent manner and upregulates ING4 expression in human glioma. J Neurooncol 2007;85:263-70. [PubMed: 17594054]

[231]. Shankar S, Srivastava RK. Involvement of Bcl-2 family members, phosphatidylinositol 3'kinase/AKT and mitochondrial p53 in curcumin (diferulolylmethane)-induced apoptosis in prostate cancer. Int J Oncol 2007;30:905-18. [PubMed: 17332930]

[232]. Han SS, Chung ST, Robertson DA, et al. Curcumin causes the growth arrest and apoptosis of B cell lymphoma by downregulation of egr-1, c-myc, bcl-XL, NF-kappa B, and p53. Clin Immunol 1999;93:152-61. [PubMed: 10527691]

[233]. Moos PJ, Edes K, Mullally JE, et al. Curcumin impairs tumor suppressor p53 function in colon cancer cells. Carcinogenesis 2004;25:1611-7. [PubMed: 15090465]

[234]. McKinsey TA, Olson EN. Cardiac histone acetylation--therapeutic opportunities abound. Trends Genet 2004;20:206-13. [PubMed: 15041175]

[235]. Yang XJ. The diverse superfamily of lysine acetyltransferases and their roles in leukemia and other diseases. Nucleic Acids Res 2004;32:959-76. [PubMed: 14960713]

[236]. Kramer OH, Gottlicher M, Heinzel T. Histone deacetylase as a therapeutic target. Trends Endocrinol Metab 2001;12:294-300. [PubMed: 11504668]

[237]. Lee CW, Lin WN, Lin CC, et al. Transcriptional regulation of VCAM-1 expression by tumor necrosis factor-alpha in human tracheal smooth muscle cells: involvement of MAPKs, NFkappaB, p300, and histone acetylation. J Cell Physiol 2006;207:174-86. [PubMed: 16288471] 
[238]. Balasubramanyam K, Varier RA, Altaf M, et al. Curcumin, a novel p300/CREB-binding protein-specific inhibitor of acetyltransferase, represses the acetylation of histone/nonhistone proteins and histone acetyltransferase-dependent chromatin transcription. J Biol Chem 2004;279:51163-71. [PubMed: 15383533]

[239]. Chen Y, Shu W, Chen W, et al. Curcumin, both histone deacetylase and p300/CBP-specific inhibitor, represses the activity of nuclear factor kappa B and Notch 1 in Raji cells. Basic Clin Pharmacol Toxicol 2007;101:427-33. [PubMed: 17927689]

[240]. Kunnumakkara AB, Diagaradjane P, Anand P, et al. Curcumin sensitizes human colorectal cancer to capecitabine by modulation of cyclin D1, COX-2, MMP-9, VEGF and CXCR4 expression in an orthotopic mouse model. Int J Cancer 2009;125:2187-97. [PubMed: 19623659]

[241]. Anand P, Sundaram C, Jhurani S, et al. Curcumin and cancer: an "old-age" disease with an "age-old" solution. Cancer Lett 2008;267:133-64. [PubMed: 18462866]

[242]. Shen SQ, Zhang Y, Xiang JJ, et al. Protective effect of curcumin against liver warm ischemia/ reperfusion injury in rat model is associated with regulation of heat shock protein and antioxidant enzymes. World J Gastroenterol 2007;13:1953-61. [PubMed: 17461496]

[243]. Wortelboer HM, Usta M, van der Velde AE, et al. Interplay between MRP inhibition and metabolism of MRP inhibitors: the case of curcumin. Chem Res Toxicol 2003;16:1642-51. [PubMed: 14680379]

[244]. Deodhar SD, Sethi R, Srimal RC. Preliminary study on antirheumatic activity of curcumin (diferuloyl methane). Indian J Med Res 1980;71:632-4. [PubMed: 7390600]

[245]. Satoskar RR, Shah SJ, Shenoy SG. Evaluation of anti-inflammatory property of curcumin (diferuloyl methane) in patients with postoperative inflammation. Int J Clin Pharmacol Ther Toxicol 1986;24:651-4. [PubMed: 3546166]

[246]. Lal B, Kapoor AK, Agrawal PK, et al. Role of curcumin in idiopathic inflammatory orbital pseudotumours. Phytother Res 2000;14:443-7. [PubMed: 10960899]

[247]. Hatcher H, Planalp R, Cho J, et al. Curcumin: from ancient medicine to current clinical trials. Cell Mol Life Sci 2008;65:1631-52. [PubMed: 18324353]

[248]. Lao CD, Ruffin MTt, Normolle D, et al. Dose escalation of a curcuminoid formulation. BMC Complement Altern Med 2006;6:10. [PubMed: 16545122]

[249]. Cheng AL, Hsu CH, Lin JK, et al. Phase I clinical trial of curcumin, a chemopreventive agent, in patients with high-risk or pre-malignant lesions. Anticancer Res 2001;21:2895-900. [PubMed: 11712783]

[250]. Shankar TN, Shantha NV, Ramesh HP, et al. Toxicity studies on turmeric (Curcuma longa): acute toxicity studies in rats, guineapigs \& monkeys. Indian J Exp Biol 1980;18:73-5. [PubMed: 6772551]

[251]. Sharma RA, McLelland HR, Hill KA, et al. Pharmacodynamic and pharmacokinetic study of oral Curcuma extract in patients with colorectal cancer. Clin Cancer Res 2001;7:1894-900. [PubMed: 11448902]

[252]. Ireson CR, Jones DJ, Orr S, et al. Metabolism of the cancer chemopreventive agent curcumin in human and rat intestine. Cancer Epidemiol Biomarkers Prev 2002;11:105-11. [PubMed: 11815407]

[253]. Shoba G, Joy D, Joseph T, et al. Influence of piperine on the pharmacokinetics of curcumin in animals and human volunteers. Planta Med 1998;64:353-6. [PubMed: 9619120]

[254]. Sharma RA, Euden SA, Platton SL, et al. Phase I clinical trial of oral curcumin: biomarkers of systemic activity and compliance. Clin Cancer Res 2004;10:6847-54. [PubMed: 15501961]

[255]. Sharma RA, Ireson CR, Verschoyle RD, et al. Effects of dietary curcumin on glutathione Stransferase and malondialdehyde-DNA adducts in rat liver and colon mucosa: relationship with drug levels. Clin Cancer Res 2001;7:1452-8. [PubMed: 11350917]

[256]. Holder GM, Plummer JL, Ryan AJ. The metabolism and excretion of curcumin (1,7-bis-(4hydroxy-3-methoxyphenyl)-1,6-heptadiene-3,5-dione) in the rat. Xenobiotica 1978;8:761-8. [PubMed: 726520]

[257]. Perkins S, Verschoyle RD, Hill K, et al. Chemopreventive efficacy and pharmacokinetics of curcumin in the $\mathrm{min} /+$ mouse, a model of familial adenomatous polyposis. Cancer Epidemiol Biomarkers Prev 2002;11:535-40. [PubMed: 12050094] 
[258]. Garcea G, Berry DP, Jones DJ, et al. Consumption of the putative chemopreventive agent curcumin by cancer patients: assessment of curcumin levels in the colorectum and their pharmacodynamic consequences. Cancer Epidemiol Biomarkers Prev 2005;14:120-5. [PubMed: 15668484]

[259]. Chiang PC, Lin SC, Pan SL, et al. Antroquinonol displays anticancer potential against human hepatocellular carcinoma cells: A crucial role of AMPK and mTOR pathways. Biochem Pharmacol. 2009

[260]. Anand P, Nair HB, Sung B, et al. Design of curcumin-loaded PLGA nanoparticles formulation with enhanced cellular uptake, and increased bioactivity in vitro and superior bioavailability in vivo. Biochem Pharmacol 79:330-8. [PubMed: 19735646]

[261]. Maiti K, Mukherjee K, Gantait A, et al. Curcumin-phospholipid complex: Preparation, therapeutic evaluation and pharmacokinetic study in rats. Int J Pharm 2007;330:155-63. [PubMed: 17112692]

[262]. Adams BK, Ferstl EM, Davis MC, et al. Synthesis and biological evaluation of novel curcumin analogs as anti-cancer and anti-angiogenesis agents. Bioorg Med Chem 2004;12:3871-83. [PubMed: 15210154]

[263]. Salmaso S, Bersani S, Semenzato A, et al. New cyclodextrin bioconjugates for active tumour targeting. J Drug Target 2007;15:379-90. [PubMed: 17613656]

[264]. Marczylo TH, Verschoyle RD, Cooke DN, et al. Comparison of systemic availability of curcumin with that of curcumin formulated with phosphatidylcholine. Cancer Chemother Pharmacol 2007;60:171-7. [PubMed: 17051370] 


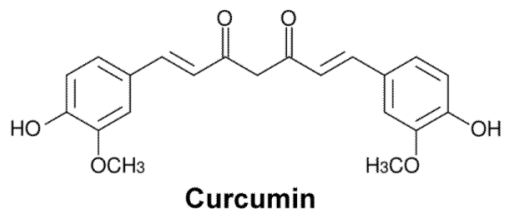

Fig. (1).

Chemical structure of curcumin. 


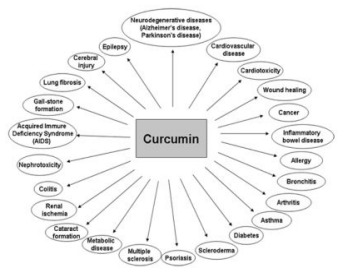

Fig. (2).

Therapeutic potential of curcumin on various human diseases. For more information, see reference [9-12]. 


\section{Table 1}

A list of molecular targets of curcumin.

Transcriptional factors

Aryl hydrocarbon receptor (AhR)^

Activating protein-1 (AP-1) $\downarrow$

Activating transcription factor 3 (ATF3) $\uparrow$

$\beta$-Catenin $\downarrow$

CCAAT/enhancer-binding protein (C/EBP) $\downarrow$

$\mathrm{C} / \mathrm{EBP}$ homologous protein (CHOP) $\uparrow$

$\mathrm{CTCF} \downarrow$

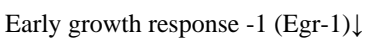

Electrophile response element (EpRE) $\uparrow$

Heat shock factor-1 $\downarrow$

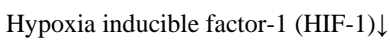

Notch-1 1

Nuclear factor erythroid 2-related factor 2 (Nrf2) $\uparrow$

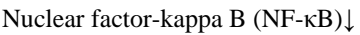

Peroxisome proliferator-activated receptor-gamma $($ PPAR- $\gamma) \uparrow$

Signal transducers and activators of transcription-1 (STAT-1) $\downarrow$

Signal transducers and activators of transcription-3 (STAT-3) $\downarrow$

Signal transducers and activators of transcription-4 (STAT-4) $\downarrow$

Signal transducers and activators of transcription-5 (STAT-5)

Wilms' tumor gene 1 (WT-1) $\downarrow$

Growth factor and growth factor receptors

Androgen receptor (AR) $\downarrow$

Chemokine (C-X-C motif) receptor 4 (CXCR 4) $\downarrow$

Connective tissue growth factor (CTGF) $\downarrow$

Epidermal growth factor (EGF) $\downarrow$

EGF-receptor $\downarrow$

Estrogen receptor-alpha (ER- $\alpha$ ) $\downarrow$

Granulocyte macrophage-colony stimulating factor (GM-CSF) $\downarrow$

Fibroblast growth factor (FGF) $\downarrow$

Hepatocyte growth factor (HGF) $\downarrow$

Human epidermal growth factor receptor-2

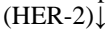

Nerve growth factor (NGF) $\downarrow$

Platelet derived growth factor (PDGF) $\downarrow$

Tissue factor (TF) $\downarrow$ 
Transforming growth factor- $\alpha$ (TGF- $\alpha) \downarrow$

TGF- $\beta \downarrow$

Vascular endothelial growth factor (VEGF) $\downarrow$

Protein kinases

Autophosphorylation-activated protein kinase

$(\mathrm{AK}) \downarrow$

$\mathrm{Ca}^{2+}$-dependent protein kinase (CDPK) $\downarrow$

EGF receptor-kinase $\downarrow$

Extracellular receptor kinase (ERK) $\downarrow$

Focal adhesion kinase (FAK) $\downarrow$

IL-1 receptor-associated kinase (IRAK) $\downarrow$

Janus kinase $(\mathrm{JAK}) \downarrow$

c-jun N-terminal kinase (JNK) $\downarrow \uparrow$

P38 mitogen-activated protein kinase (p38 MAPK) $\downarrow \uparrow$

Mammalian target of rapamycin (mTOR) $\downarrow$

Phosphorylase kinase $(\mathrm{PhK}) \downarrow$

Protamine kinase (cPK) $\downarrow$

Protein kinase A (PKA) $\downarrow$

$\mathrm{PKB} \downarrow$

$\mathrm{PKC} \downarrow$

pp60 $60^{\mathrm{c}-\mathrm{src}} \downarrow$

Spleen Tyrosine Kinase (Syk) $\downarrow$

Adhesion molecules

Endothelial leukocyte adhesion molecule-1

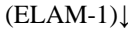

E-selectin $\downarrow$

Intracellular cell adhesion molecule-1 (ICAM-1) $\downarrow$

P-selectin $\downarrow$

Vascular cell adhesion molecule-1 (VCAM-1) $\downarrow$

Inflammatory cytokines

Chemokine (C-X-C motif) ligand 1 (CXCL1) $\downarrow$

CXCL2 $\downarrow$

Interleukin-1 $\beta$ (IL-1 $\beta) \downarrow$

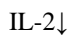

IL-5 $\downarrow$

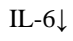

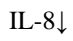

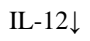

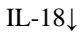

Monocyte chemoattractant protein-1 (MCP-1) $\downarrow$

Macrophage inflammatory protein-1 alpha

Curr Drug Targets. Author manuscript; available in PMC 2012 March 1. 
(MIP-1 $\alpha) \downarrow$

Tumor necrosis factor alpha (TNF- $\alpha$ )

\section{Enzymes}

Arylamine $\mathrm{N}$-acetyltransferases- $1 \downarrow$

ATPase $\downarrow$

Cyclooxygenase-2 (COX-2) $\downarrow$

Desaturase $\downarrow$

DNA polymerase $\downarrow$

Farnesyl protein transferase (FPTase) $\downarrow$

Gluthathione-S-transferase (GST) $\downarrow \uparrow$

Glutamyl cysteine ligase (GCL) $\uparrow$

Hemeoxygenase-1 (HO-1) $\uparrow$

Inducible nitric oxide synthase (iNOS) $\downarrow$

5-lipoxygenase (5-LOX) $\downarrow$

Matrix metalloproteinase (MMP) $\downarrow$

NAD(P)H:quinone oxidoreductase $\downarrow$

Ornithine decarboxylase (ODC) $\downarrow$

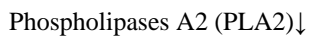

Src homology 2 domain-containing tyrosine

Phosphatase $2 \uparrow$

Telomerase $\downarrow$

Xanthine oxidase (XO) $\downarrow$

Apoptosis-related protein

$\mathrm{Bak} \uparrow$

$\mathrm{Bax} \uparrow$

$\operatorname{Bim} \uparrow$

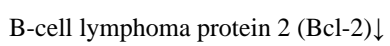

Bcl-xL $\downarrow$

Caspase- $3 \uparrow$

Caspase- $7 \uparrow$

Caspase- $8 \uparrow$

Caspase-9 $\uparrow$

Cellular FLICE inhibitory protein (c-FLIP) $\downarrow$

Death receptor 4 (DR4)^

Death receptor 5 (DR5)

Fas $\uparrow$

Fas-associated death domain (FADD) $\uparrow$

Inhibitor of apoptosis protein (IAP) $\downarrow$

Noxa $\uparrow$

Puma $\uparrow$

Survivin $\downarrow$ 


\section{Others}

Cyclin D1 $\downarrow$

DNA fragmentation factor 40-kd subunit $\uparrow$

Heat-shock protein 70 (HSP 70)^

Multi-drug resistance protein (MRP) $\downarrow$

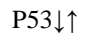

P300/CREB-binding protein (CBP) $\downarrow$

Urokinase-type plasminogen activator (uPA) $\downarrow$

$\mathrm{uPAR} \downarrow$ 